\title{
Investigating sources of gaseous oxidized mercury in dry deposition at three sites across Florida, USA
}

\author{
M. Sexauer Gustin ${ }^{1}$, P. S. Weiss-Penzias ${ }^{2}$, and C. Peterson ${ }^{1}$ \\ ${ }^{1}$ Department of Natural Resources and Environmental Science, University of Nevada-Reno, 1664 North Virginia Street, \\ Reno, Nevada 89557, USA \\ ${ }^{2}$ University of California, Santa Cruz, Department of Microbiology and Environmental Toxicology, Santa Cruz, \\ California, USA
}

Correspondence to: M. S. Gustin (mgustin@cabnr.unr.edu)

Received: 3 May 2012 - Published in Atmos. Chem. Phys. Discuss.: 25 July 2012

Revised: 24 September 2012 - Accepted: 26 September 2012 - Published: 11 October 2012

\begin{abstract}
During 2009-2010, the State of Florida established a series of air quality monitoring stations to collect data for development of a statewide total maximum daily load (TMDL) for mercury (Hg). At three of these sites, located near Ft. Lauderdale (DVE), Pensacola (OLF), and Tampa Bay (TPA), passive samplers for the measurement of air $\mathrm{Hg}$ concentrations and surrogate surfaces for measurement of $\mathrm{Hg}$ dry deposition were deployed. While it is known that $\mathrm{Hg}$ in wet deposition in Florida is high compared to the rest of the United States, there is little information on Hg dry deposition. The objectives of the work were to: (1) investigate the utility of passive sampling systems for $\mathrm{Hg}$ in an area with low and consistent air concentrations as measured by the Tekran ${ }^{\circledR}$ mercury measurement system, (2) estimate dry deposition of gaseous oxidized $\mathrm{Hg}$, and (3) investigate potential sources. This paper focuses on Objective 3 . All sites were situated within $15 \mathrm{~km}$ of $1000 \mathrm{MW}$ electricity generating plants (EGPs) and major highways. Bi-weekly dry deposition and passive sampler Hg uptake were not directly correlated with the automated Tekran ${ }^{\circledR}$ system measurements, and there was limited agreement between these systems for periods of high deposition. Using diel, biweekly, and seasonal Hg observations, and ancillary data collected at each site, the potential sources of $\mathrm{Hg}$ deposited to surrogate surfaces were investigated. With this information, we conclude that there are three major processes/sources contributing to $\mathrm{Hg}$ dry deposition in Florida, with these varying as a function of location and time of year. These include: (1) in situ oxidation of locally and regionally derived $\mathrm{Hg}$ facilitated by mobile source emissions, (2) indirect and direct inputs of Hg from local EGPs,
\end{abstract}

and (3) direct input of $\mathrm{Hg}$ associated with long range transport of air from the northeastern United States. Based on data collected with the surrogate surface sampling system, natural background dry deposition for Florida is estimated to be $0.03 \mathrm{ng} \mathrm{m}^{-2} \mathrm{~h}^{-1}$. Deposition associated with mobile sources is $0.10 \mathrm{ng} \mathrm{m}^{-2} \mathrm{~h}^{-1}$ at TPA and DVE, and $0.03 \mathrm{ng} \mathrm{m}^{-2} \mathrm{~h}^{-1}$ at OLF. Long range transport contributes $0.8 \mathrm{ng} \mathrm{m}^{-2} \mathrm{~h}^{-1}$ in the spring. At DVE $\sim 0.10 \mathrm{ng} \mathrm{m}^{-2} \mathrm{~h}^{-1}$ is contributed directly or indirectly from local point sources. We also suggest based on the data collected with the Tekran ${ }^{\circledR}$ and passive sampling systems that different chemical forms of GOM are associated with each of these sources.

\section{Introduction}

Annual mercury $(\mathrm{Hg})$ wet deposition $\left(\mu \mathrm{g} \mathrm{m}^{-2}\right)$ reported for Florida and along the Gulf Coast are often the highest in the United States (National Atmospheric Deposition Program, 2012). The potential sources of $\mathrm{Hg}$ in precipitation to Florida have been studied by many groups over the past $15 \mathrm{yr}$ and have been suggested to be local and anthropogenic, regional with inputs from the marine boundary layer, and global, derived from air transported in the free troposphere (cf. Dvonch et al., 1999 and 2005; Guentzel et al., 2001; Landing et al., 2010; Engle et al., 2008, 2010). Several modeling efforts have also focused on unraveling the sources of $\mathrm{Hg}$ in wet deposition (cf. Selin and Jacob, 2008; Holmes et al., 2010; Zhang et al., 2012), with observations best simulated using 
an $\mathrm{OH} / \mathrm{O}_{3}$ oxidation mechanism in the GEOS-CHEM model (cf. Selin and Jacob, 2008).

An alternate explanation for the higher $\mathrm{Hg}$ wet deposition in Florida, is simply higher precipitation amounts in this region relative to the rest of the conterminous US (Prestbo and Gay, 2009) since this area has a similar proportion of anthropogenic $\mathrm{Hg}$ sources as the Midwest and Northeastern United States (Butler et al., 2008). Comparing precipitation amounts and $\mathrm{Hg}$ wet deposition measured over several years, using data from the Mercury Deposition Network (MDN) and National Trends Network (NTN) of the National Atmospheric Deposition Program (NADP), wet deposition is not necessarily correlated with higher precipitation amounts relative to sites along the eastern seaboard. Additionally, the suggestion that $\mathrm{Hg}$ deposition is derived from the marine boundary layer is not supported by data from other coastal locations with high amounts of rainfall such as Washington State ( 5 to $7 \mu \mathrm{g} \mathrm{Hg} \mathrm{m}^{-3}$ versus 16 to $23 \mu \mathrm{g} \mathrm{m}^{-3}$ ). Lastly, Butler et al. (2008) (years 1998-2005) and Prestbo and Gay (2009) (years 1996-2005) found that deposition and concentrations measured in the Southeast did not decline as coal combustion facilities implemented $\mathrm{Hg}$ control technologies as was found in other regions. One explanation for the lack of a trend in Florida is that implementation of $\mathrm{Hg}$ control technologies on other major sources (medical waste incinerators and municipal waste combustion) occurred prior to this time (Prestbo and Gay, 2009). Despite the many years of study, the source of $\mathrm{Hg}$ in wet deposition in Florida remains a topic of debate.

The forms of $\mathrm{Hg}$ believed to dominate dry deposition are gaseous oxidized Hg (GOM) and particulate bound (PBM) (Lindberg and Stratton, 1998). Currently the chemical forms of GOM are unknown, and the potential mechanisms important for formation are uncertain (cf. Ariya et al., 2009; Hynes et al., 2009; Lin et al., 2006; Subir et al., 2011, 2012). Forms thought to be dominant include $\mathrm{HgCl}_{2}, \mathrm{HgBr}_{2}$, and $\mathrm{HgO}$ (Feng et al., 2004; Schroeder and Munthe, 1998; Seigneur et al., 1994), and others have been suggested such as $\mathrm{HgS}$, $\mathrm{HgSO}_{4}, \mathrm{HgSO}_{3}, \mathrm{Hg}\left(\mathrm{NO}_{2}\right)_{2}$, and $\mathrm{Hg}(\mathrm{OH})_{2}$ (Feng et al., 2004; Lindberg and Stratton, 1998; Seigneur et al., 1994). That said, the contribution of GEM to deposition also needs to be considered given the predominance of this form in the atmosphere (Gustin, 2012; Zhang et al., 2012).

In 2009, the State of Florida, along with the Southeastern Aerosol Research and Characterization (SEARCH) network, put in place a series of monitoring stations to collect data that would provide the basis for formulating a statewide Total Maximum Daily Load (TMDL) for Hg and load allocations for point sources within the policy mandates of the Clean Water Act (http://www.dep.state.fl.us/water/ tmdl/merctmdl.htm). Within the framework of this project, and only through significant cooperation, the University of Nevada-Reno (UNR) deployed surrogate surfaces for the measurement of gaseous oxidized mercury (GOM) dry deposition $\left(\mathrm{GOM}_{\mathrm{ss}}\right)$ (Lyman et al. 2007, 2009a), passive samplers for determining air concentrations of GOM $\left(\mathrm{GOM}_{\mathrm{ps}}\right)$
(Lyman et al., 2010), and passive samplers for determining air concentrations of total gaseous mercury (TGM) (Gustin et al., 2011). The goal of this study was to test the utility of these simple, cost-effective methods for estimating air $\mathrm{Hg}$ concentrations at three sites across the State, estimate dry deposition, and develop a framework for understanding sources. The first two objectives were addressed in Peterson et al. (2012) showing that dry deposition estimates using a bi-directional atmospheric resistance model and Tekran ${ }^{\circledR}$ analyzer derived $\mathrm{Hg}$ concentrations were lower than surrogate surface derived dry deposition primarily at DVE and TPA, and was similar to that measured at OLF except in the spring. Some spatial and temporal trends in surrogate surface and passive sampler data were not seen in the Tekran observations and therefore suggested that the passive samplers may be collecting form(s) of GOM or $\mathrm{Hg}$ (II) not collected by the Tekran ${ }^{\circledR}$ system.

Because of these observations, information gained from the automated and passive systems are utilized together to investigate sources of $\mathrm{Hg}$ in dry deposition. Criteria air pollutant concentrations and detailed assessment of wind directions are applied to provide a more robust platform for interpreting observed trends. This work also expands upon previous work investigating potential sources of $\mathrm{Hg}$ in dry deposition to two SEARCH network sites, one in Florida and Georgia (Lyman et al., 2009a; Weiss-Penzias et al., 2011). Although GOM dry deposition is thought to contribute only $5-15 \%$ of the Hg input annually to the southeastern United States (Lyman et al., 2009a; Peterson et al., 2012), our working hypothesis was source tracking during dry periods would be simpler given the complexity of rain events.

\section{Methods}

\subsection{Measurements}

Passive samplers and surrogate surfaces were co-located with a SEARCH, and two Florida Department of Environmental Protection managed locations. A transect was formed by these sampling sites across the State with Davie, near Fort Lauderdale (DVE; Lat. $26.085^{\circ} \mathrm{N}$, Long. $80.240^{\circ} \mathrm{W}$ ) in the southeast; a central location near Tampa (TPA; Lat. $27.913^{\circ} \mathrm{N}$, Long. $82.375^{\circ} \mathrm{W}$ ); and a site in the northwest on the panhandle at Outlying Landing Field near Pensacola (OLF; Lat. $30.550^{\circ} \mathrm{N}$, Long. $87.374^{\circ} \mathrm{W}$ ). All sites are influenced by marine air with the Gulf of Mexico being south of OLF $(29 \mathrm{~km})$ and west of TPA $(48 \mathrm{~km})$, and the Atlantic Ocean $14 \mathrm{~km}$ to the east of DVE (Fig. 1). Additional site information is provided in Peterson et al. (2012).

Automated GEM, GOM and PBM data were collected by the Tekran ${ }^{\circledR}$ system at 5 to $6 \mathrm{~m}$ above ground level (a.g.l.) (detection limits $0.1 \mathrm{ng} \mathrm{m}^{-3}, 1 \mathrm{pg} \mathrm{m}^{-3}$, and $1 \mathrm{pg} \mathrm{m}^{-3}$ respectively; Eric Edgerton, personal communication). It is important to note that variability between co-located instruments 
Table 1. General location and emission inventory data for EGPs within a $50 \mathrm{~km}$ radius of each site. The $2002 \mathrm{Hg}$ data is from the EPA NEI inventory and the $2009 \mathrm{Hg}$ data is from an estimate provided from the Florida Department of Environmental Protection using US EPA CAMD hourly heat input data and EPRI correlation coefficients for percent removal.

\begin{tabular}{|c|c|c|c|c|c|c|c|c|c|c|c|c|}
\hline $\begin{array}{l}\text { Facility } \\
\text { Name }\end{array}$ & $\begin{array}{l}\text { Nearest } \\
\text { Site }\end{array}$ & $\begin{array}{l}\text { Distance to } \\
\text { Site }(\mathrm{km})\end{array}$ & $\begin{array}{l}\text { Direction: Site } \\
\text { to Facility }\end{array}$ & $\begin{array}{l}\text { Primary } \\
\text { Fuel }\end{array}$ & $\begin{array}{l}\text { Output } \\
\text { MW }\end{array}$ & $\begin{array}{l}\mathrm{Hg} \\
\text { Inventory } \\
\text { Year }\end{array}$ & $\begin{array}{l}\text { Total } \mathrm{Hg} \\
\mathrm{kg} \mathrm{yr}^{-1}\end{array}$ & $\begin{array}{l}\text { GOM } \\
\mathrm{kg} \mathrm{yr}^{-1}\end{array}$ & $\begin{array}{l}\text { PBM } \\
\mathrm{kg} \mathrm{yr}^{-1}\end{array}$ & $\begin{array}{l}\mathrm{SO}_{2} \\
\mathrm{Mg} \mathrm{yr}^{-1}\end{array}$ & $\begin{array}{l}\mathrm{NO}_{\mathrm{x}} \\
\mathrm{Mg} \mathrm{yr}^{-1}\end{array}$ & $\begin{array}{l}\mathrm{CO} \\
\mathrm{Mg} \mathrm{yr}^{-1}\end{array}$ \\
\hline Wheelabrator North & DVE & 24 & NE & Waste & 67 & 2002 & 46 & 26 & 9 & 163 & 1250 & 88 \\
\hline Wheelabrator South & DVE & 5 & $\mathrm{E}$ & Waste & 66 & 2002 & 53 & 31 & 11 & 131 & 1214 & 63 \\
\hline Lauderdale & DVE & 5 & $\mathrm{E}$ & Natural gas & 1812 & 2002 & $\mathrm{nr}$ & $\mathrm{nr}$ & $\mathrm{nr}$ & 97 & 2125 & 216 \\
\hline Port Everglades & DVE & 13 & $\mathrm{E}$ & Oil & 1717 & 2002 & 13 & 4 & 3 & 3574 & 2902 & 492 \\
\hline Covanta (Montanay) & DVE & 21 & SSW & Waste & 77 & 2002 & 7 & 4 & 1 & 27 & 1150 & 694 \\
\hline Bayside & TPA & 5 & $\mathrm{~W}$ & Natural Gas & 1859 & 2002 & 3 & 1 & 1 & 17 & 548 & 288 \\
\hline Big Bend & TPA & 14 & SSW & Coal & 1995 & 2009 & 48 & 15 & 1 & 8725 & 4387 & 8317 \\
\hline Pasco Co. RRF & TPA & 33 & $\mathrm{~W}$ & Waste & 31 & 2002 & 14 & 8 & 3 & 14 & 749 & 21 \\
\hline Bartow & TPA & 26 & W & Oil & 465 & 2002 & 7 & 2 & 1 & 31 & 456 & 138 \\
\hline Bayboro & TPA & 35 & WSW & Oil & 232 & 2002 & 23 & 7 & 5 & 9 & 63 & 0 \\
\hline Crist & OLF & 15 & $\mathrm{E}$ & Coal & 1071 & 2009 & 70 & 60 & 2 & 3425 & 5320 & 545 \\
\hline
\end{tabular}

has been reported to be on the order of 0.3 to $20 \%$ for GEM, 9 to $40 \%$ for GOM, and up to $70 \%$ for PBM (Gustin and Jaffe, 2010; Steffen et al., 2012). Criteria air pollutants $\left(\mathrm{O}_{3}\right.$, $\mathrm{CO}, \mathrm{SO}_{2}, \mathrm{NO}_{\mathrm{y}}$ and $\mathrm{NO}$ ) and meteorological parameters were measured at $10 \mathrm{~m}$ a.g.l. (c.f. Peterson et al., 2012). For all data, hourly means were time stamped by the end of the hour. For GOM and PBM, this represents the previous two hours of sampling due to a one hour sampling and analyses cycle.

Surrogate surfaces for GOM dry deposition $\left(\mathrm{ng} \mathrm{m}^{-2} \mathrm{~h}^{-1}\right)$ and passive samplers, an indirect measure of GOM $\left(\mathrm{pg} \mathrm{h}^{-1}\right)$ concentrations, were placed at 3 to $5 \mathrm{~m}$ a.g.l. (Peterson et al., 2012). These were shipped and deployed over 13 months ( $n=28$ biweekly samples), from July 2009 through July 2010, by State of Florida and SEARCH personnel. Surrogate surfaces were deployed in triplicate over two weeks with two field blanks per site. Passive samplers consisted of triplicate membranes and one membrane blank deployed simultaneous for each 2 week period. Samplers and membranes were deployed, collected and analyzed using a protocol developed by Lyman et al. (2009a; 2010). Details regarding quality control for this study are reported by Peterson et al. (2012). The surrogate surface methods have also been applied by Castro et al. (2012) and recently, in a 2 yr study in the Southwestern United States at 6 locations (Mark Sather, US EPA Region 6, personnel communication, 27 April 2012).

Seasonal mean air $\mathrm{Hg}$, trace gas and meteorological data were averaged using hourly reported values. Data was bulked seasonally, where Spring represents March to May, Summer (June-August), Fall (September-November) and Winter (December-February). Statistical analyses were done using Minitab ${ }^{\circledR} 15$ and Origin ${ }^{\circledR}$ with a significance level of $p<0.05$ applied.

\subsection{Regional emissions inventories}

Sources of criteria air pollutants at all three sites are mobile and stationary. In order to support a population of $19 \times 10^{6}$, the State of Florida has $\sim 90$ electrical generation plants
(EGPs) with an output greater than $25 \mathrm{MW}$ (11 coal fired). The impact of these on data collected at each site will depend upon wind direction, energy production, fuel type and general proximity. Each site is within $15 \mathrm{~km}$ of an EGP producing greater than $1000 \mathrm{MW}$ and with significantly greater $\mathrm{SO}_{2}$ emissions relative to other facilities in the vicinity (Table 1; Fig. 1).

The population of the area will influence the density of mobile sources. The DVE site, situated in the South Florida Metropolitan area, hosts $5.6 \times 10^{6}$ people, and was in close proximity to US Interstate 595, the Florida Turnpike and the Port Everglades Expressway. The TPA location (population base of $4 \times 10^{6}$ ) was centered between major routes in and out of the city (i.e. US Interstate 75 and 4). The OLF site is located to the northwest of Pensacola (population $0.45 \times 10^{6}$ ) and just south of US Interstate 10, a major route across northern Florida (Fig. 1). The population of Florida increases seasonally during the winter and spring when tourism is a major industry. In 2008 , there were an estimated $82.5 \times 10^{6}$ visitors to the State (http://www.floridatransportationindicators.org).

For our data analyses annual $\mathrm{SO}_{2}$ and $\mathrm{NO}_{\mathrm{x}}$ emissions inventories for EGPs in Florida were obtained from the Florida Department of Environmental Protection website (http://webapps.dep.state.fl.us/DarmReports/ eaor/fads/search.do), and daily values from the US EPA Clean Air Markets Division website (http://ampd.epa.gov/ ampd/) (Table 1). $\mathrm{NO}_{\mathrm{x}} / \mathrm{SO}_{2}$ ratios for each facility were determined from reported output in tons by converting to moles using the molar mass for $\mathrm{SO}_{2}$ and $\mathrm{NO}_{2}$, and then calculating the ratio $\mathrm{NO}_{\mathrm{X}} / \mathrm{SO}_{2}$.

Mercury emissions for EGPs that were not coal fired were estimated using data from the 2002 EPA NEI (http://ampd. epa.gov/ampd/). For the coal burning utilities, emission data for 2009 were obtained from the Florida Division of Environmental Protection (Greg White, Florida Division of Environmental Quality, personal communication, August 2011). The latter were from the Florida Electric Power Coordination Group, Inc. and based on the US EPA Clean Air Markets 

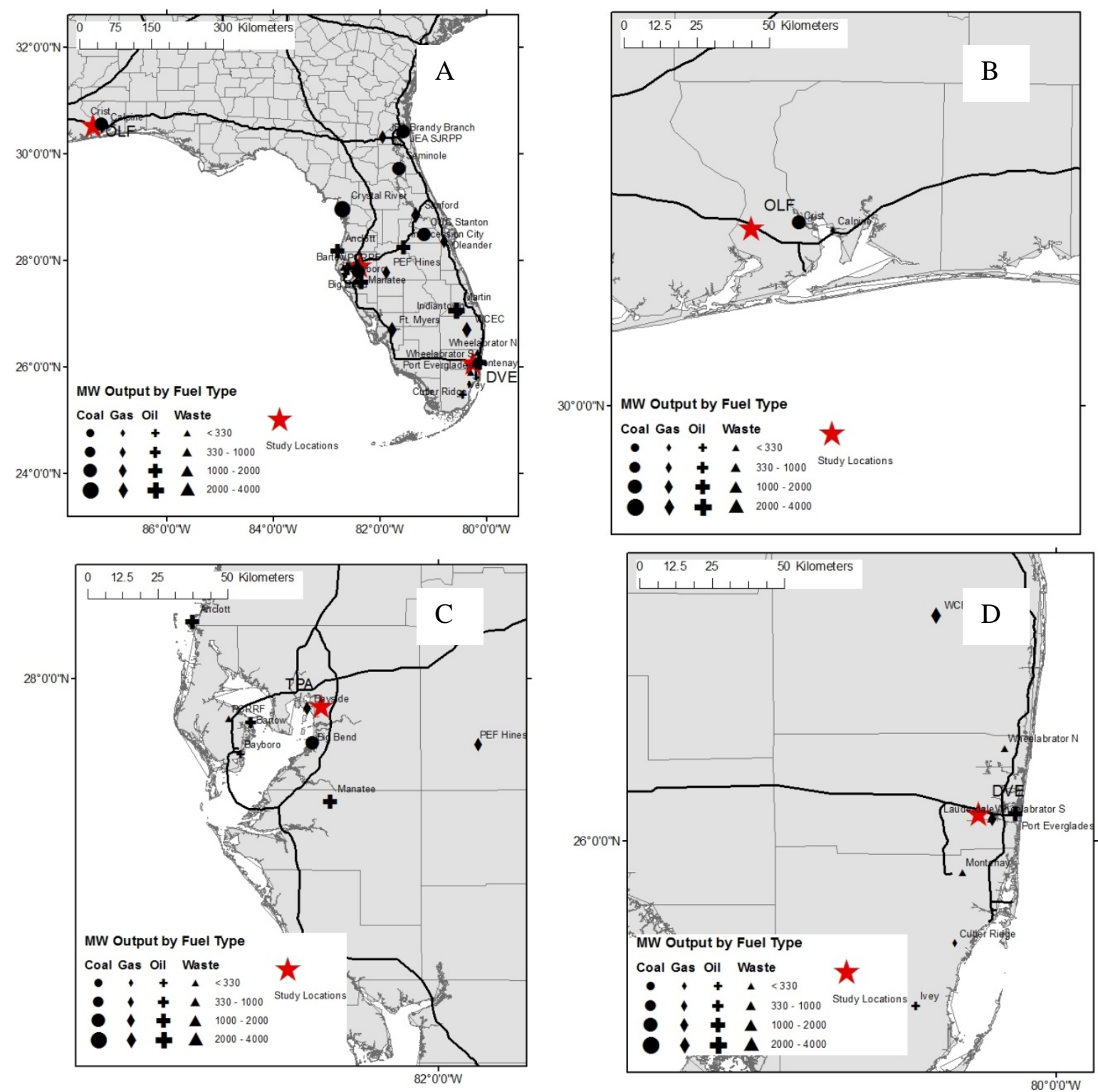

Fig. 1. (A) Map of Florida, located in the southeastern United States, showing the study locations and Florida electrical generation units (EGUs) with $>1000 \mathrm{MW}$ output segregated by primary fuel type. Also shown are more detailed maps of area surrounding study sites and all EGPs within a $50 \mathrm{~km}$ radius for (B) Pensacola, (C) Tampa and (D) Ft. Lauderdale areas.

Division (CAMD) hourly heat input data and Electric Power Research Institute (EPRI) correlation coefficients for percent removal for 2009. Based on these, total Hg and GOM emissions for Plant Crist were by far the largest for any single facility. However, a flue gas desulfurization (FGD) system came online at the site in December 2009 and as such; the inventory values do not reflect those for the entire study. It is important to note for the incinerators and oil based facilities, it is unclear whether emission estimates are based on empirical data (Table 1).

\subsection{Classification of GOM data}

Following the approach outlined in Weiss-Penzias et al. (2011), GOM concentration enhancement "events" are defined as time periods when at least one GOM concentration measurement from the Tekran ${ }^{\circledR}$ system was greater than the 97th percentile based on all concentrations at each site (31, 11 , and $16 \mathrm{pg} \mathrm{m}^{-3}$ for DVE, OLF and TPA, respectively). The duration of the event was then designated as the time over which the Tekran ${ }^{\circledR}$ derived GOM concentrations were at or above the annual mean for each site (Supplement Tables 1 and 2). Events were then classified as "1", "2", or 
"Unclassified" based on $\mathrm{SO}_{2}$ concentrations and wind directions during the peak GOM concentrations. Class 1 events include those when $\mathrm{SO}_{2}$ concentrations were greater than the mean of peak $\mathrm{SO}_{2}$ values for all events at each site, and when concurrent wind directions were from the closest large EGP: 70 to 110 degrees for both DVE and OLF, and 160-200 degrees for TPA. Conversely, Class 2 events had peak $\mathrm{SO}_{2}$ concentrations that were less than the mean of all events and wind directions from outside the ranges stated for Class 1 events. Unclassified events met the GOM criteria but not the $\mathrm{SO}_{2}$ and wind direction criteria for the Class 1 or Class 2 events.

\subsection{Back trajectory analysis}

Seventy-two hour back trajectories were calculated using HYSPLIT v4.8 (Draxler and Hess, 1997) for the 5 events with the highest GOM concentrations. Meteorological fields at $40 \mathrm{~km}$ resolution from the National Center for Environmental Prediction Eta Data Assimilation System (EDAS) served as input for the procedure. Trajectories were initialized at $6 \mathrm{~h}$ intervals during the 24-h period encompassing the peak GOM concentration of each event. The area of initialization was a $0.5 \times 0.5$ degree grid of 9 starting locations evenly spaced around each site. Four starting altitudes were used: 500, 1000, 1500, and $2000 \mathrm{~m}$ above modeled ground level. The goal of using trajectory analysis in this study was to investigate regional and larger scale transport patterns that may have influenced GOM and GOM dry deposition. As such, it is common practice to have the lowest starting altitude be well above the surface, to avoid erroneous trajectories due to sub-grid processes and turbulent flow. This generated 144 back trajectories for each event. Each hourly location of a trajectory is denoted as a "trajectory point".

Gridded frequency distributions (GFDs) were generated by averaging the number of trajectory points in $1 \times 1 \mathrm{de}$ gree grid cells over the domain of interest (Weiss-Penzias et al., 2009, 2011). GFDs were also generated to show only those grid cells that contained a high proportion $(>90 \%)$ of the trajectory points that were at altitudes greater than the HYSPLIT modeled boundary layer height, and the distribution of precipitation along the trajectory paths. The location probability represents the fraction of trajectory points in a given cell relative to the number of trajectory points in the most populated cell. Uncertainties in the three-dimensional locations of trajectories (the horizontal uncertainty is roughly $20 \%$ of the distance traveled) were minimized by calculating trajectories at the nine locations and four altitudes around each sampling site, thus creating a data set with sufficient statistical power to overcome the major limitations of the computational procedure (sub grid processes, turbulent flow, and convection; Stohl, 1998; Stohl et al., 2003).

\subsection{Meso- and synoptic scale wind patterns in Florida}

When interpreting trends in air pollutants, one must consider the meso- and synoptic- scale meteorological conditions impacting each site. On the synoptic scale during the cooler seasons, the near surface flow in Florida is dominated by passing cold fronts. This is especially true for North Florida since not all fronts reach South Florida. The winds typically are from the west or northwest after frontal passage and then shifts to the south after several days with the approach of the next frontal systems. In the middle and upper levels of the atmosphere, the cooler season flow is dominated by passing troughs and ridges. The flow generally is from the southwest ahead of a trough and from the northwest after the trough passes (before the next ridge arrives). Once again, this is most pronounced for North Florida.

During the summer, synoptic patterns in Florida are dominated by the Bermuda/Azores high, and a lobe of high pressure that sometimes forms over the Gulf of Mexico. Depending on the location of the Bermuda high and whether there is a Gulf of Mexico lobe, both the surface and upper level winds can range from east, to south, to west, and occasionally, have a component from the north. Summer is the sea breeze season in Florida, and the three sampling sites experience a regular diel variation of this meso-scale circulation, i.e. onshore flow during the day (sea breeze) and weaker offshore flow at night (land breeze) (Fig. 2). The direction and strength of the large scale flow greatly affects the intensity and strength and inland penetration of the sea breeze (Henry Fuelberg, Florida State University, personal communication, 31 March and 2 May 2012).

\section{Results}

\subsection{Summary of observations and interspecies correlations}

As summarized by Peterson et al. (2012), annual GOM concentrations as measured by the Tekran ${ }^{\circledR}$ system at DVE $\left(7 \mathrm{pg} \mathrm{m}^{-3}\right)$ were significantly $(p<0.05)$ higher than those measured at OLF $\left(2 \mathrm{pg} \mathrm{m}^{-3}\right)$ and TPA $\left(3 \mathrm{pg} \mathrm{m}^{-3}\right)$ (Supplement Table 1). Annual GEM concentrations were also significantly higher at DVE (1.4 versus 1.2 and $1.3 \mathrm{ng} \mathrm{m}^{-3}$, respectively). PBM concentrations were significantly higher at OLF relative to the two other sites ( 3 versus $2 \mathrm{pg} \mathrm{m}^{-3} p<0.05$ ).

Mean annual and seasonal ozone $\left(\mathrm{O}_{3}\right)$ concentrations were highest at OLF, with those measured at DVE and TPA being similar to each other. Highest $\mathrm{O}_{3}$ values were observed at all sites in the spring. Mean seasonal and annual CO concentrations were highest in the winter and lowest in the summer at all sites, and highest at TPA relative to the other sites. Seasonal mean $\mathrm{CO}$ values are at or above the upper limit of those considered ambient values for remote areas of 50 to $150 \mathrm{ppb}$ (Finlayson-Pitts and Pitts, 2000). The highest $\mathrm{NO}$ and $\mathrm{NO}_{\mathrm{y}}$ 

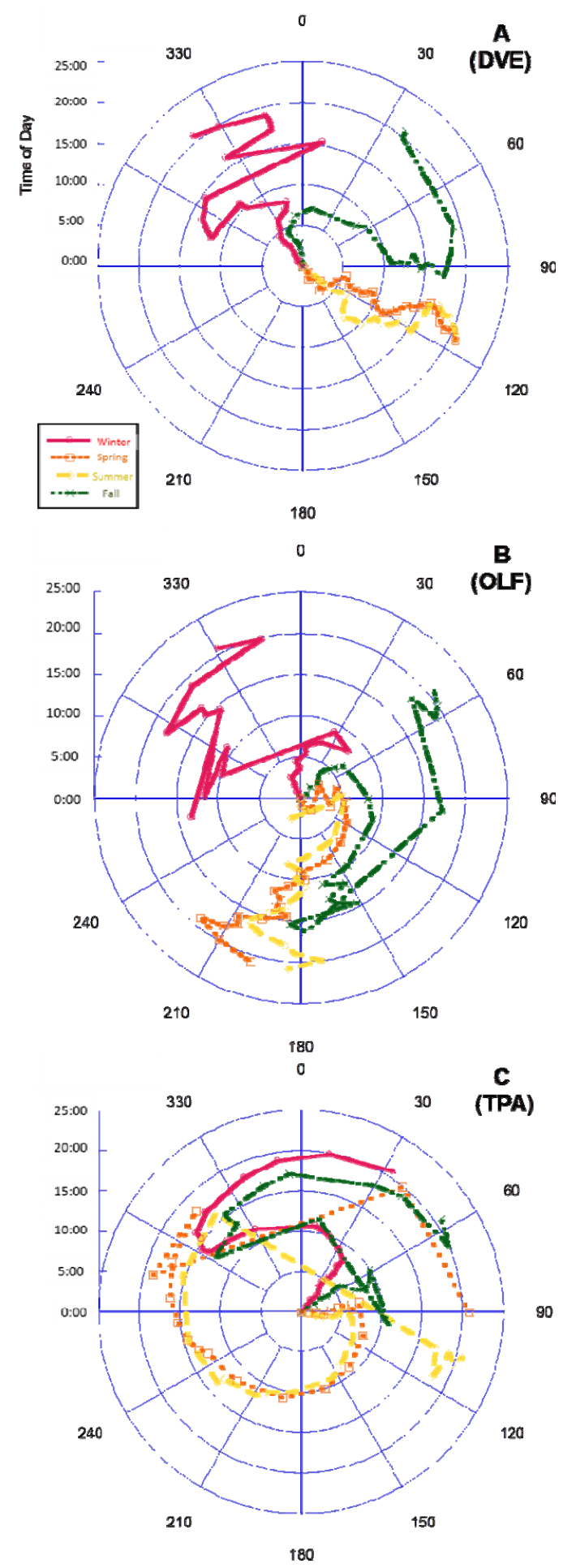

Fig. 2. Prevailing wind direction over the course of $24 \mathrm{~h}$ for each season for (A) DVE, (B) OLF and (C) TPA.

values were observed in the winter and fall, and the lowest in the spring. DVE and TPA had comparable mean NO and $\mathrm{NO}_{\mathrm{y}}$ concentrations in the spring and winter, that were significantly higher than observations at OLF. At all sites, annual and seasonal mean $\mathrm{SO}_{2}$ concentrations were higher than values reported for clean continental and marine air $(\sim 100 \mathrm{pptr}$, Finlayson-Pitts and Pitts, 2000) and in general highest at TPA. The TPA site did not often receive air that passed over the local EGP. There was a slight peak in $\mathrm{SO}_{2}$ concentrations in the morning at all sites concurrent with observed $\mathrm{CO}$ and NO concentrations suggesting a contribution from mobile sources (Fig. 3a).

Trends in air $\mathrm{Hg}$ and criteria air pollutant concentrations reflect the chemistry of the air as impacted by local emissions, air transported into the area associated with synoptic patterns, and the general meteorological conditions (i.e. temperature, light, relative humidity) that influence chemical processing. Since NO is a short lived pollutant, the highest concentrations at DVE reflects nearby EGPs and mobile source outputs, while the higher NO values at DVE and TPA relative to OLF are due to the greater mobile source density at these two locations. Since winter and spring are drier (Fig. 3b-RH) this would create a setting more conducive for photochemical oxidation reactions. These are also the time periods when the population density of the State increases due to the influx of people. $\mathrm{NO}_{\mathrm{y}}$ and $\mathrm{CO}$ concentrations were also higher during these seasons. Higher $\mathrm{O}_{3}$ concentrations, observed at all sites in the spring, as well as drier air (Fig. 3a and Supplement Table 1), and lower NO concentrations, suggest the input of upper troposphere air in the spring. Higher PBM concentrations were observed in the spring at OLF. Engle et al. (2008) also observed that fine particulate matter $\mathrm{Hg}$ concentrations were highest in January through March of 2006 in this area. Deposition to the surrogate surfaces was also high across all sites at this time (see discussion below).

GOM and PBM were combined for linear regression analyses with criteria air pollutants (Supplement Table 2). At DVE on an annual time and seasonal time step, GOM + PBM was correlated with $\mathrm{SO}_{2}, \mathrm{RH}$ (negative) and $\mathrm{O}_{3}$ (positive) with the best coefficients for the latter two in the winter and spring data. At OLF on an annual time step, correlations were strongest for $\mathrm{RH}, \mathrm{O}_{3}$ and $\mathrm{SO}_{2}$. But similar to DVE, the $r^{2}$ values for $\mathrm{RH}$ and $\mathrm{O}_{3}$ are strongest for winter and spring, followed by fall, and lowest in the summer. The correlation with $\mathrm{SO}_{2}$ was best in the summer and fall for this site, when wind directions from the east were prevalent. At TPA correlations are not as clear with only RH being well correlated on annual and seasonal time steps, and best correlated in the spring. $\mathrm{O}_{3}$ was similarly correlated with GOM + PBM for spring, summer and fall for this site. These trends suggest that dry conditions are an important characteristic of air masses with GOM. 


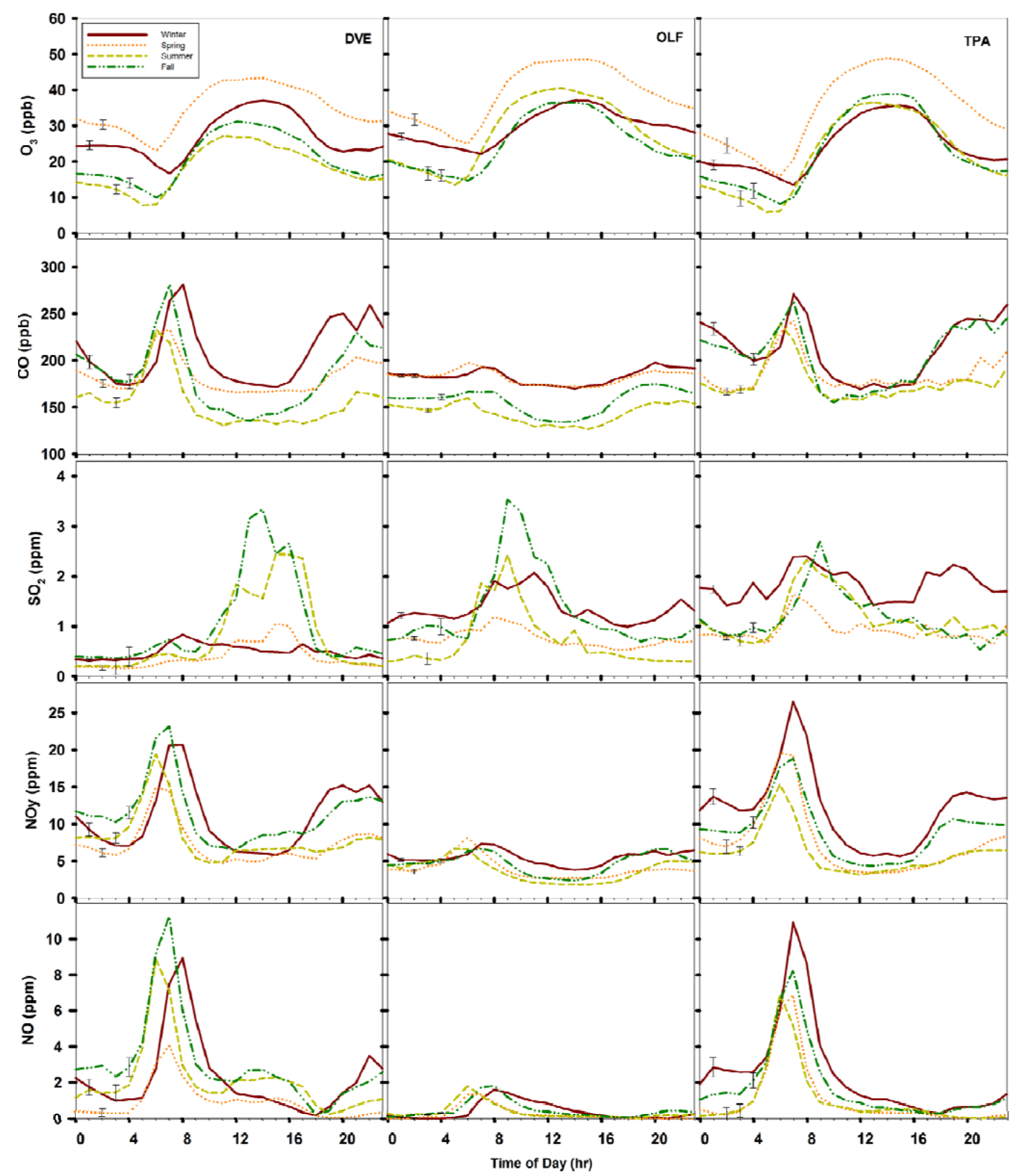

Fig. 3a. Diel bin plots of ozone $\left(\mathrm{O}_{3}\right)$, carbon monoxide $(\mathrm{CO})$, sulfur dioxide $\left(\mathrm{SO}_{2}\right)$, and nitrogen oxides $\left(\mathrm{NO}_{\mathrm{y}}\right.$ and $\left.\mathrm{NO}\right)$ developed using 2-h seasonal means. Error bars represent the standard error associated with the two hour data with the first error bar representing winter values, second bar being spring, the third bar is summer and fourth bar is fall. Panels show data for DVE, OLF and TPA from left to right.

\subsection{Diel cycles}

GOM concentrations were highest at DVE with values increasing at $\sim 08: 00 \mathrm{LT}$, peaking between 12:00 and 16:00 LT and then declining (Fig. 3b). During spring, summer and fall over the course of the day, wind came from the general direction of EGPs (Fig. 2). The fact that GOM exhibited a diel pattern of continually increasing concentrations over the course of a day, coinciding with increases in wind speeds, which would theoretically result in decreased concentrations, suggests that GOM was being gradually produced by photochemical reactions over the course of the day and not directly emitted from the EGPs. Alternatively, this pattern could reflect mixing of GOM containing air down to the surface as the planetary boundary layer expands over the course of a day. It is noteworthy that during the winter, the same pattern in GOM concentrations was observed during the day when the mean prevailing wind direction was from the northwest (not the general direction of an EGP) (Fig. 2). Limited aircraft data has suggested higher GOM in the free troposphere 


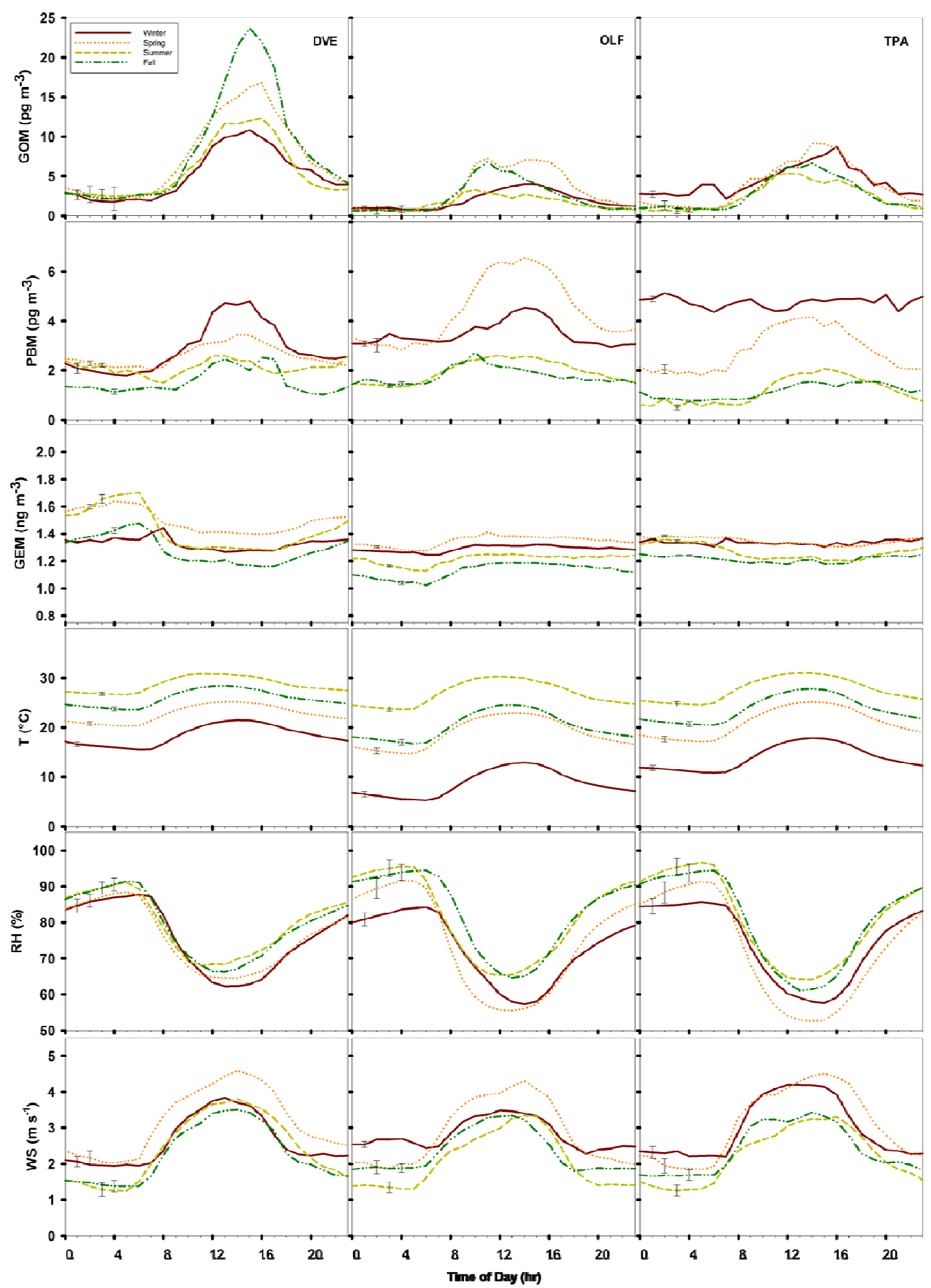

Fig. 3b. Diel bin plots of GOM, PBM, GEM, temperature, relative humidity (RH) and windspeed (WS) also derived using 2-h seasonal means.

of Florida (Silliman et al., 2007). Dvonch et al. (2005) suggested using volume weighted $\mathrm{Hg}$ concentrations and trace elements in precipitation that at DVE the "feed air" incorporated local urban emissions.
At OLF, the diel maximum in GOM concentrations: (1) occurred in the morning in the fall; (2) was bimodal in the spring and summer, occurring in the morning and afternoon; and (3) consisted of a broad peak in the winter. In the winter, seasonal mean winds were derived from the northwest 
coming from the general direction of I-10. In the spring, summer and fall, based on mean airflow patterns transport to the site was from vicinity of Plant Crist (00:00 to 09:00 LT), and then shifted to the south from Pensacola (Fig. 2). The early morning increase of GOM concurrent with $\mathrm{SO}_{2}$ concentrations suggests that a component of the GOM measured was directly or indirectly associated with emissions from Plant Crist (cf. Edgerton et al., 2006; Engle et al., 2008). However, the afternoon peak in the spring, winter and summer when transport was in general not from the EGP, suggests that there is an additional source or process responsible for GOM formation.

At TPA, GOM concentrations measured across all seasons increased starting at $\sim 08: 00 \mathrm{LT}$ building up over the course of the day and then declining at night similar to observations at DVE (Fig. 3b). Based on mean seasonal patterns, air coming into this site from 10:00 to 12:00 LT had the potential to be influenced by emissions from the Big Bend facility (Fig. 2). However of the three sites, the correlation between $\mathrm{SO}_{2}$ and $\mathrm{GOM}+\mathrm{PBM}$ at TPA was the lowest.

As suggested by Engle et al. (2008), the afternoon GOM maxima observed in Florida could be explained by photochemical production of GOM, entrainment from the free troposphere, and/or transport onto the land as local winds bring air from the marine boundary layer onto the continent. We suggest here that in situ oxidation of GEM associated with mobile source pollutants is an additional factor to consider as a mechanism for production. This could be associated with reactions with primary and secondary pollutants. For example, sulfur is an important component of diesel emissions, as are volatile organic compounds and reactive oxygen species that are converted over the day to less reactive secondary organic aerosols (Biswas et al., 2009). Naturally produced oxidants could also be important given the subtropical setting. It is possible that the $\mathrm{OH}$ radical could play a role in GOM formation (c.f. Pal and Ariya, 2004) indirectly, since Calvert and Lindberg (2005) suggested inhibition of this reaction in the real atmosphere. Additionally, if GOM was produced directly by the $\mathrm{OH}$ radical a more symmetrical curve in GOM around midday would be expected (c.f. Lyman and Gustin, 2009). Reactions with $\mathrm{O}_{3}$ should also not be ruled out for: (1) this oxidant is available at 1000 times the concentration of GEM, and (2) Peterson et al. (2012) showed, using the $\mathrm{Pal}$ and Ariya (2004) reaction rates and $\mathrm{O}_{3}$ concentrations similar to those measured in Florida, that 5 to $10 \mathrm{pg} \mathrm{m}^{-3}$ $\mathrm{HgO}$ could be produced per hour. Based on the change in Tekran ${ }^{\circledR}$ derived GOM concentrations over the course of the day, GOM measured with this method could be accounted for by this production rate.

PBM concentrations were highest in the winter at DVE and TPA, when temperatures were cooler. For OLF PBM concentrations were highest in the spring. Recent modeling work by Amos et al (2012) showed, using empirical data across 5 sites that the gas phase fraction of $\mathrm{Hg}$ (II) could range from $90 \%$ in warm air to $10 \%$ in cold air with high aerosols.

Diel GEM concentrations were the most variable at DVE, differing by up to $30 \%$ in the summer (Fig. 3b). GOM +PBM as measured by the Tekran ${ }^{\circledR}$ system cannot account for this difference. At OLF, GEM increased over the course of the day across each season by 0.05 to $0.1 \mathrm{ng} \mathrm{m}^{-3}$ with higher values in the spring and winter. Observations at TPA were fairly constant over the course of a day and higher in the winter and spring.

\subsection{Trends in passive sampler $\mathrm{Hg}$ deposition and uptake}

The GOM $\mathrm{ss}_{\mathrm{ss}}$ measures potential dry deposition $\left(\mathrm{ng} \mathrm{m}^{-2} \mathrm{~h}^{-1}\right)$ that is a function of the chemical form's deposition velocity, and the turbulence observed at the site. Since the surrogate surface is open to the air, $\mathrm{Hg}$ bound to aerosols could be collected. Additionally, the surface could be a site where heterogeneous oxidation and reduction reactions of GEM and GOM occur, respectively. Lyman et al. (2009) investigated the impact of wind velocity on surrogate surface deposition versus Tekran ${ }^{\circledR}$ derived GOM concentrations, and found that there was little impact of wind speed on the correlation.

In contrast, the $\mathrm{GOM}_{\mathrm{ps}}$ sampler is designed to be diffusion driven and is a surrogate measure of concentration. Passive sampling systems are based on Fick's Law that states that the rate at which a substance diffuses through another of a similar phase is directly proportional to the concentration gradient. If uptake $\left(\mathrm{pg} \mathrm{h}^{-1}\right)$ is higher, then the air concentration is higher. Based on comparison of empirically derived sampling rates with theoretical sampling rates, this sampler has a slight wind effect (Lyman et al, 2010). Site settings and wind speeds across seasons were similar between locations during the study. However, in the spring at all sites and in the winter at TPA wind velocities were higher by $\sim 1 \mathrm{~cm} \mathrm{~s}^{-1}$.

Some items to consider when assessing the $\mathrm{GOM}_{\mathrm{ss}}$ data include: (1) Peterson et al. (2012) reported deposition velocities, calculated using surrogate surface measured deposition and bi-weekly Tekran ${ }^{\circledR}$ GOM concentrations (that were fairly constant), of 0.1 to $7 \mathrm{~cm} \mathrm{~s}^{-1}$ and suggested this reflected different forms of GOM being present at these three sites; (2) based on limited tests, some GOM (15\%) could be lost from the surrogate surfaces when sampling over two weeks, and as such, actual deposition could be higher than recorded; and (3) bi-weekly deposition data was adjusted for the associated field blanks and a factor of $0.2 \mathrm{ng} \mathrm{m}^{-2} \mathrm{~h}^{-1}$. The latter was based on the assumption that when the Tekran ${ }^{\circledR}$ system is measuring less than $1 \mathrm{pg} \mathrm{m}^{-3}$ $\mathrm{GOM}$, the $\mathrm{Hg}$ on the membrane is contamination from the mount (cf. Lyman et al., 2009). However, no holding tests have been done to verify this, and if this factor is not warranted, then deposition would increase for all sites (Peterson et al., 2012). 


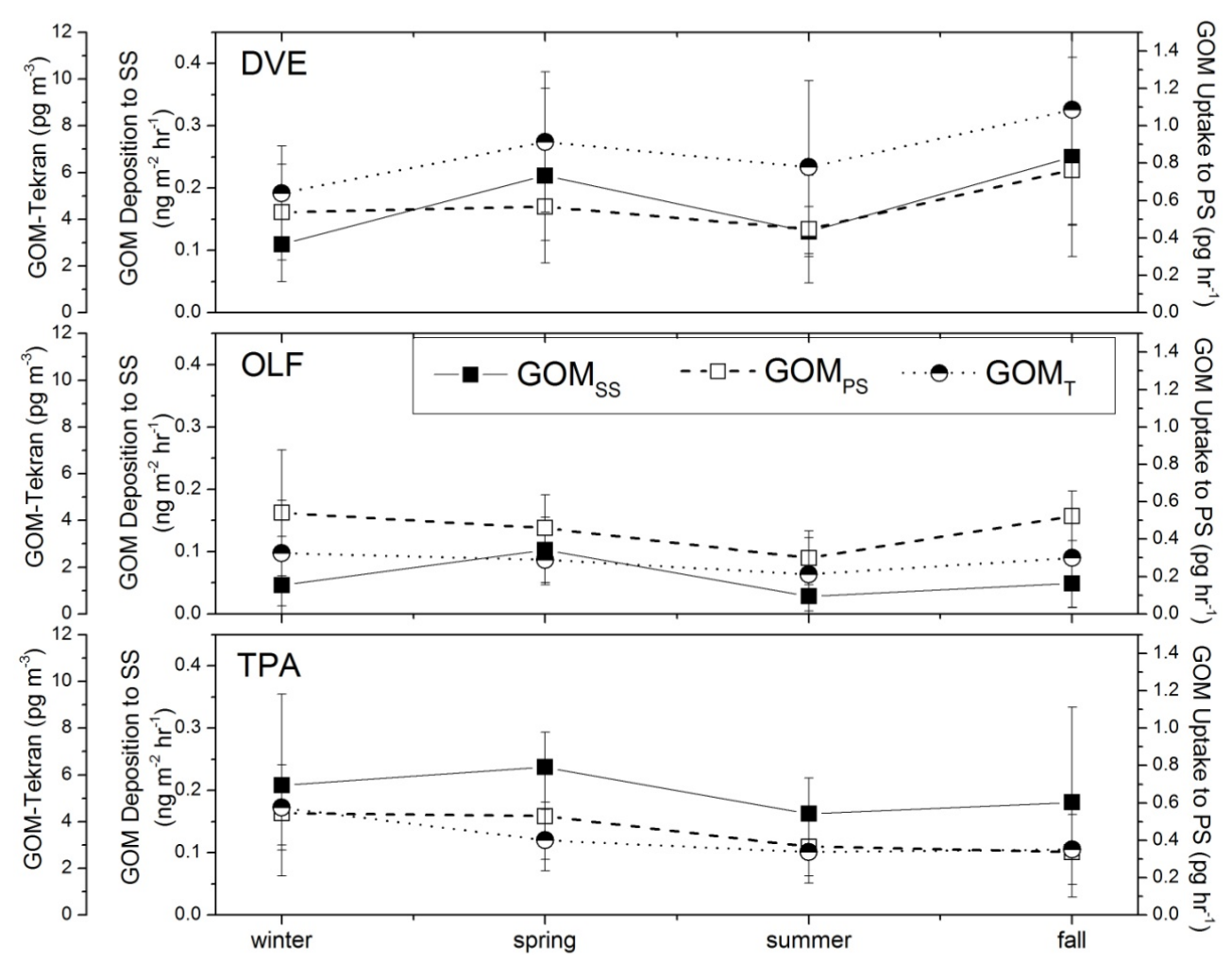

Fig. 4. Seasonal means \pm 1 sd of Tekran-GOM air concentration (GOMT), GOM dry deposition to a surrogate surface (GOMSS), and GOM uptake to a passive sampler (GOMPS) measured at DVE, OLF and TPA.

As pointed out in Peterson et al. (2012), using data from all three sites $\mathrm{GOM}_{\mathrm{ps}}$ and $\mathrm{GOM}_{\mathrm{ss}}$ data were statistically significantly correlated $\left(r^{2}=0.15\right)$. The low correlation coefficient likely reflects the fact that the former is a surrogate for concentration and the latter a measure of potential deposition. Using the data from all three sites over the entire year of study both of these were significantly correlated with biweekly measurements made by the Tekran ${ }^{\circledR}$ system $\left(r^{2}\right.$ values of 0.19 and 0.25 , respectively). However, on a site specific basis, at OLF, GOM as measured by the Tekran ${ }^{\circledR}$ system was significantly correlated with the $\mathrm{GOM}_{\mathrm{ss}}$ and $\mathrm{GOM}_{\mathrm{ps}}$ $\left(r^{2}=0.37\right.$ and 0.34$)$, while at TPA data was correlated only for $\mathrm{GOM}_{\mathrm{ss}}$ data $\left(r^{2}=0.31\right)$. If one assumes that the passive systems are accurately recording $\mathrm{Hg}$ (II), then one explanation is that the Tekran system, as configured, is best measuring the form(s) of $\mathrm{Hg}$ (II) that are prevalent at OLF when compared to the other sites. The form of GOM at OLF exhibited, in general, the lowest overall deposition velocities (c.f. Peterson et al., 2012).

For all three sites, mean $\mathrm{GOM}_{\mathrm{ss}}$ measured deposition was highest in the spring and lower in the summer (Fig. 4). The higher spring values are associated with a change in synoptic wind patterns, as supported by the criteria air pollutant data, and this was the time with the highest mean wind speeds at DVE and TPA but not OLF (cf. Peterson et al., 2012). The lowest values in the summer reflect the fact this time pe- riod is when the highest precipitation occurs and thus, less dry conditions (c.f. Butler et al., 2008). Since dry deposition happens all the time and over all different surfaces, this may reflect faster removal of GOM during wet conditions for soluble species like GOM. This also suggests that the surrogate surfaces as designed may not be capturing this process.

At DVE, the summer deposition rate was $0.1 \mathrm{ng} \mathrm{m}^{-2} \mathrm{~h}^{-1}$, while the total deposition over the year of study was $180 \mathrm{ng} \mathrm{m}^{-2}$ and $448 \mathrm{ng} \mathrm{m}^{-2}$ for the data with and without the $0.2 \mathrm{ng} \mathrm{m}^{-2} \mathrm{~h}^{-1}$ factor, respectively (Peterson et al., 2012). Deposition rates double in the fall, a time period with higher $\mathrm{SO}_{2}, \mathrm{NO}$ and $\mathrm{NO}_{\mathrm{y}}$ concentrations and lower RH (Fig. 3b). The latter would promote conditions for photochemistry and increase the concentration of GOM.

GOM chemistry and concentration, and atmospheric turbulence will affect deposition. For the former, Lin et al. (2006) found the deposition velocity for $\mathrm{HgO}$ $\left(6.86 \mathrm{~cm} \mathrm{~s}^{-1}\right)$ was two-fold higher than that for $\mathrm{HgCl}_{2}$ $\left(3.44 \mathrm{~cm} \mathrm{~s}^{-1}\right)$ using the resistance dry deposition model of Wesley (1989). Deposition and deposition velocities (cf. Peterson et al., 2012) were greatest at TPA, with a mean summer deposition value of $0.16 \mathrm{ng} \mathrm{m}^{-2} \mathrm{~h}^{-1}, \sim 0.2 \mathrm{ng} \mathrm{m}^{-2} \mathrm{~h}^{-1}$ in the fall and winter, and $0.24 \mathrm{ng} \mathrm{m}^{-2} \mathrm{~h}^{-1}$ in the spring. Higher values in the fall and winter may reflect additional traffic during this time. Mercury brought into the area by long range transport, based on event data described below and in 

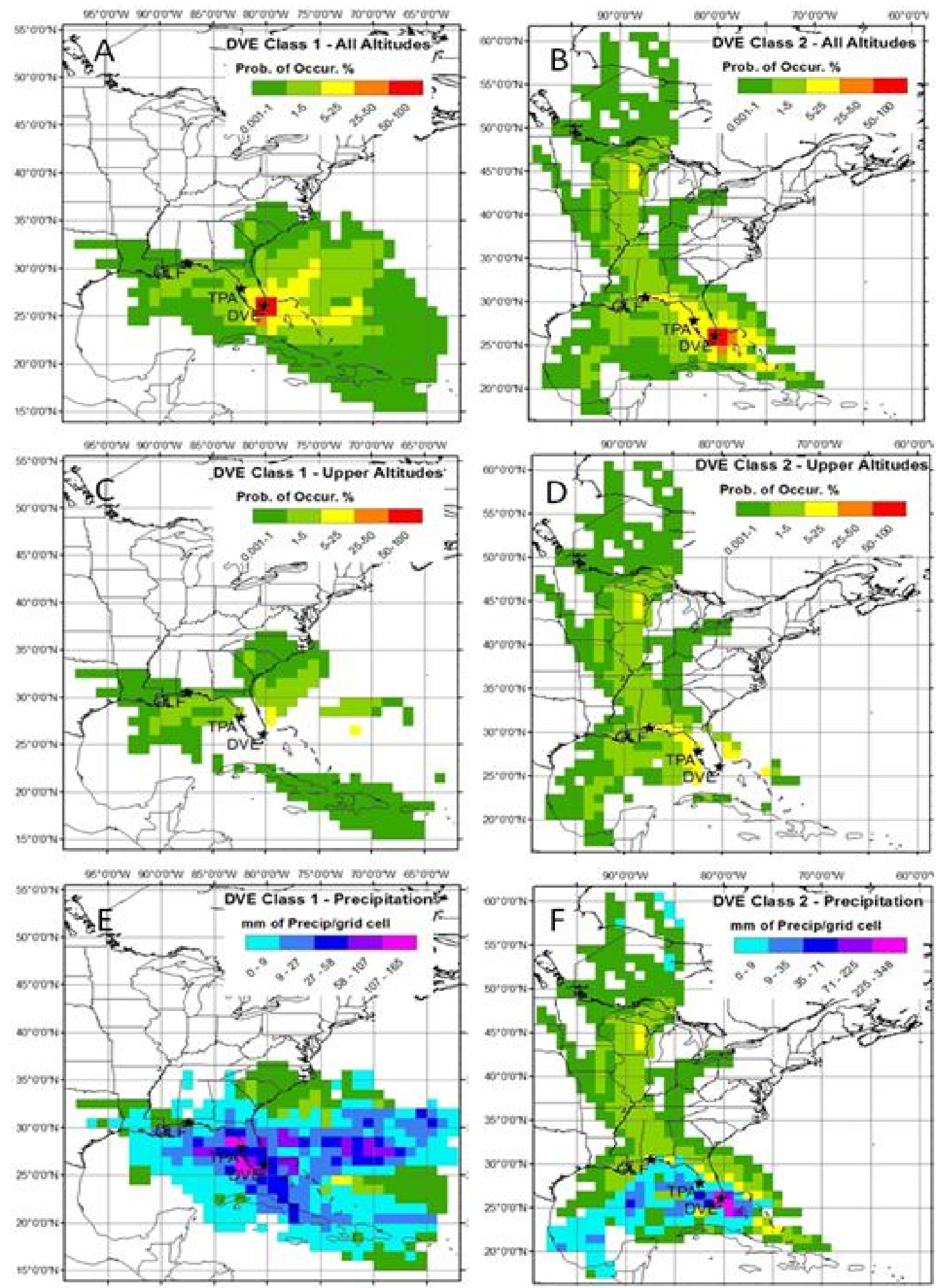

Fig. 5. Gridded frequency distributions of back trajectories for the five highest GOM concentration event days Classes 1 and 2 at the DVE site. (A) Horizontal location probabilities for Class 1 events. (B) Horizontal location probabilities for Class 2 events. (C) Same as A, but with color removed from grid cells with $>90 \%$ of trajectory points having altitudes below the modeled boundary layer. (D) Same as (C) except for Class 2 events. (E) and (F) Modeled precipitation distributions for Classes 1 and 2 events overlain on the horizontal location probabilities. 

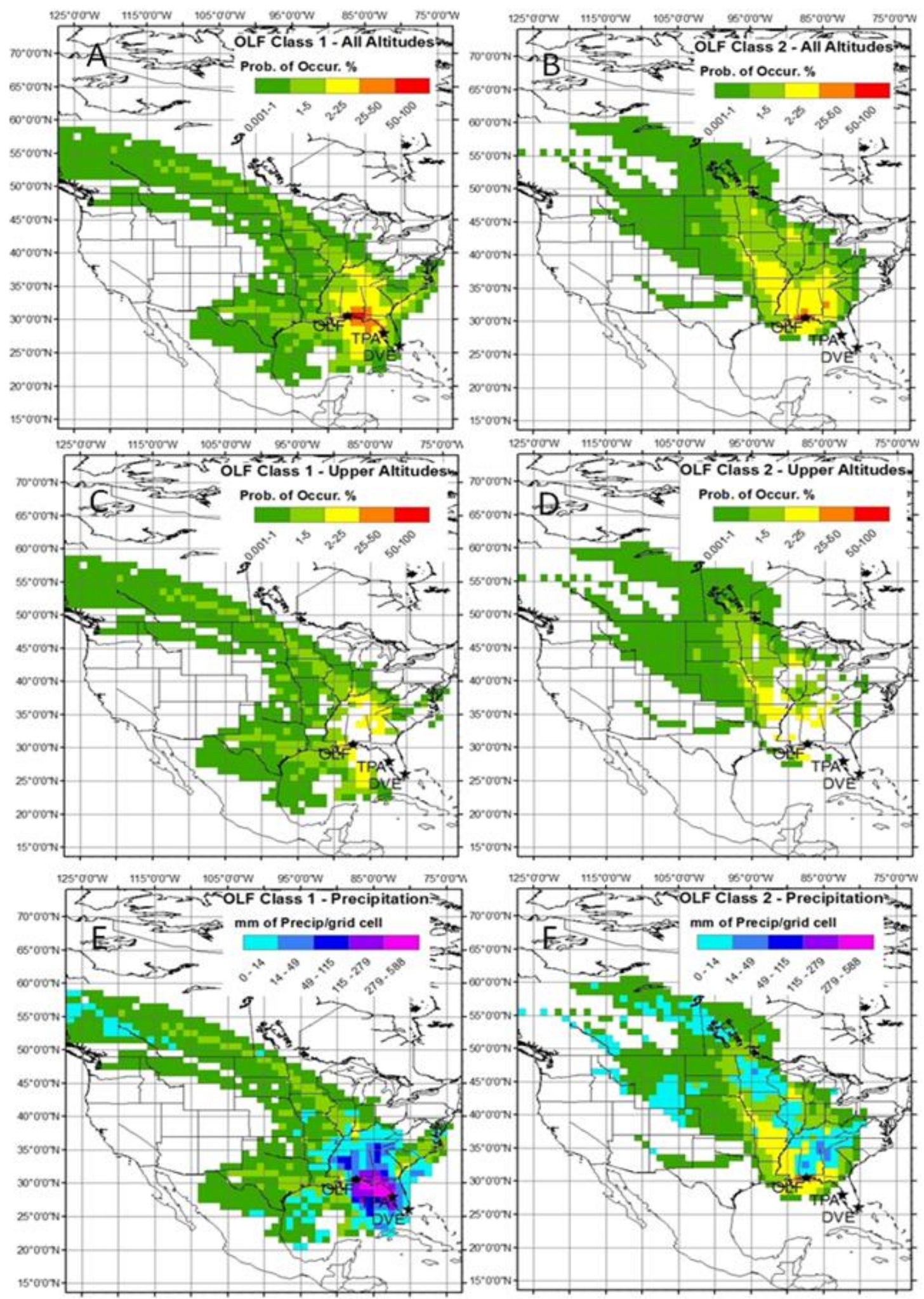

Fig. 6. Gridded frequency distributions of back trajectories for the five highest GOM concentration event days Classes 1 and 2 at the OLF site. (A) Horizontal location probabilities for Class 1 events. (B) Horizontal location probabilities for Class 2 events. (C) Same as (A), but with color removed from grid cells with $>90 \%$ of trajectory points having altitudes below the modeled boundary layer. (D) Same as (C) except for Class 2 events. (E) and (F) Modeled precipitation distributions for Classes 1 and 2 events overlain on the horizontal location probabilities. 

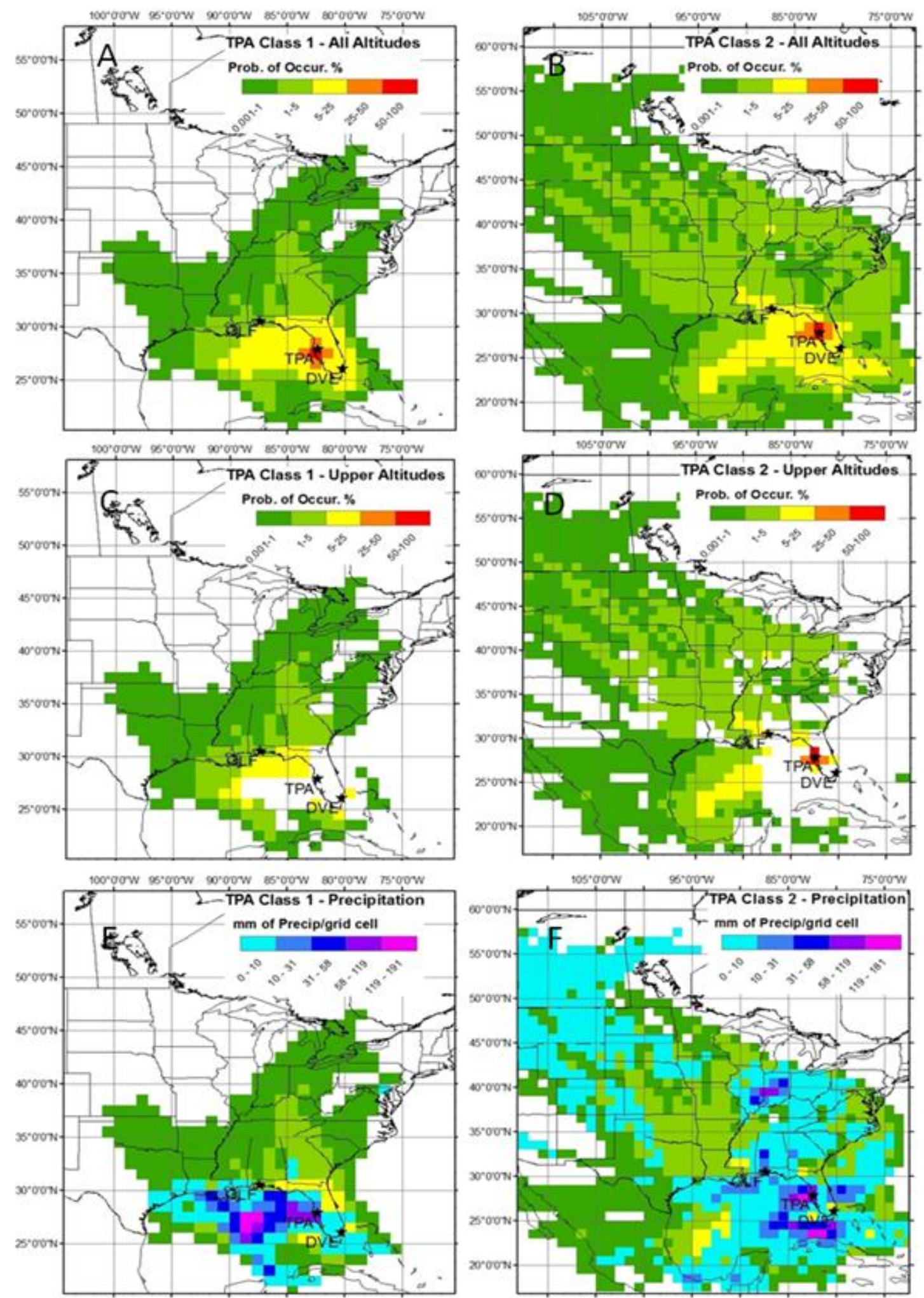

Fig. 7. Gridded frequency distributions of back trajectories for the five highest GOM concentration event days Classes 1 and 2 at the TPA site. (A) Horizontal location probabilities for Class 1 events. (B) Horizontal location probabilities for Class 2 events. (C) Same as (A), but with color removed from grid cells with $>90 \%$ of trajectory points having altitudes below the modeled boundary layer. (D) Same as (C) except for Class 2 events. (E) and (F) Modeled precipitation distributions for Classes 1 and 2 events overlain on the horizontal location probabilities. 
Weiss Penzias et al. (2011), is likely contributing to the additional deposition measured in the spring (see below event analyses). At OLF, mean deposition was $\sim 2$ times higher in the spring $\left(0.11 \mathrm{ng} \mathrm{m}^{-2} \mathrm{~h}^{-1}\right)$ relative to the winter, summer and fall $\left(0.06,0.03\right.$, and $0.03 \mathrm{ng} \mathrm{m}^{-2} \mathrm{~h}^{-1}$, respectively). The higher summer value at TPA relative to the other sites may be due to the location of the sampling site in an area of high traffic density. Since the Tekran ${ }^{\circledR}$ measured GOM air concentrations were similar between OLF and TPA this suggests a higher dry deposition velocity for the form occurring at this site and that it was not being measured by this instrument.

It is noteworthy here, that Marsik et al. (2007), using a water based surrogate surface positioned over a mixed saw grass and cattail stand in Florida in Feb to March 1999 and June 2000, obtained dry deposition rates of $0.5 \mathrm{ng} \mathrm{m}^{-2} \mathrm{~h}^{-1}$ and $0.24 \mathrm{ng} \mathrm{m}^{-2} \mathrm{~h}^{-1}$, respectively, with spring rates being greater. Our values would be more comparable if the $0.2 \mathrm{ng} \mathrm{m}^{-2} \mathrm{~h}^{-1}$ adjustment factor was not applied. Also, previous work done in 2007-2008 also showed that $\mathrm{GOM}_{\mathrm{ss}}$ deposition was enhanced during the spring relative to other seasons at the OLF site and another site near Atlanta (YRK) (Lyman et al., 2009; Weiss-Penzias et al., 2011).

Assuming passive sampler uptake is an indicator of air concentrations, annual averages showed DVE $>$ TPA $>$ OLF with lowest mean value reported for the summer at all three sites. The highest period $\mathrm{GOM}_{\mathrm{ps}}$ uptake was the winter at DVE; winter and fall at OLF; and winter and spring at TPA. These are time periods associated with increased mobile sources density at all sites, and long range transport at TPA.

Peterson et al. (2012) showed that 2-week integrated Tekran-GOM was weakly correlated with $\mathrm{GOM}_{\mathrm{ss}}$, and $\mathrm{GOM}_{\mathrm{ps}}$ observations for all sites; but on an individual site basis only well correlated at OLF. This is in contrast to previous work (Lyman et al., 2009,2010; Castro et al., 2012) that showed for rural areas, observations made with these two methods were correlated. Using an inferential model (Zhang et al., 2012) showed that deposition measured with these samplers was similar to modeled values measured in a rural area in Maryland, USA. In contrast, Peterson et al. (2012) and Lyman et al. (2007) showed using a similar model that surrogate surface deposition was underestimated. Peterson et al. (2012) found the model better simulated deposition measured at OLF relative to TPA and DVE. Lyman et al. (2007) found that the $\mathrm{GOM}_{\mathrm{ss}}$ deposition was consistently higher than the modeled value and the disparity was not consistent across all seasons. Model outputs will be impacted by the parameters used and the assumptions applied. The use of the values of alpha and beta in the model developed by Lyman et al (2007), applied by Peterson et al (2012), were modified based on based on the expected chemistry of GOM instead of using $\mathrm{HNO}_{3}$. Lyman et al. (2007) showed through sensitivity analyses that changes in chemical species dependent values and land use categories could significantly impact model deposition velocities. Based on these observations we hypoth- esize that use of one chemical species in a model may not allow for adequate simulation of dry deposition across space and time.

\subsection{Detailed analysis of GOM events}

GOM events occurred most often in the late morning and afternoon, with none at night. Most events occurred on different days. With respect to all three types of events, mean GOM concentrations were highest and GEM lowest in association with Class 1 events, while PBM concentrations were highest in Class 2 events (Table 2). Mean dewpoint temperature $\left(T_{\mathrm{dp}}\right)$ was higher in the Class 1 events for all sites, while for Class 2 and Unclassified events values were comparable. As specified, Class 1 events had wind directions from the general direction of the EGPs, while Class 2 events were not from this direction and predominantly from the north and south. In general, Unclassified events originated from the north.

Using the mean values in Table 2, for DVE and OLF, Class 1 events had lower $\mathrm{O}_{3}$ and higher NO concentrations than Class 2 and Unclassified events, but these were similar across events at TPA. The criteria pollutant concentrations during Class 1 events suggest that pollutants from local source are contributing. Class 1 events tended to occur in the fall at DVE (52\%) and at OLF (50\%), when prevailing wind directions were from the direction of the local EGPs (Fig. 2). The mean peak GOM concentration was $\sim 15 \mathrm{pg} \mathrm{m}^{-3}$ higher for Class 1 versus Class 2 events at all sites. In contrast, the average over the entire event was $\sim 7 \mathrm{pg} \mathrm{m}^{-3}$ higher for DVE and OLF but not TPA. We suggest that during these selected events the EGP are indirectly and directly contributing GOM to the sites. $\mathrm{CO}$ was higher in Class 2 and Unclassified events at DVE and OLF, but the same at TPA across events. At TPA, $\mathrm{NO}_{\mathrm{y}}$ was lower in Class 1 events while NO was consistent across events.

Looking in detail at the $\mathrm{NO}_{\mathrm{y}}$ versus $\mathrm{SO}_{2}$ relationships during Class 1 events (Supplement Fig. 3) at DVE, TPA and OLF regression coefficients explains 57, 0 and $14 \%$, respectively. There is a considerable range in $\mathrm{NO}_{\mathrm{y}}$ values at low $\mathrm{SO}_{2}$ concentrations. At DVE, the slope is similar to the annual $\mathrm{NO}_{\mathrm{y}} / \mathrm{SO}_{2}$ ratio of 0.81 for the nearby large oil based EGP. At OLF the slope for the field based $\mathrm{NO}_{\mathrm{y}} / \mathrm{SO}_{2}$ relationship is similar to the annual ratio for the facility $(0.64)$ for 2009 prior to the addition of a FGD scrubber.

The GOM/ $/ \mathrm{SO}_{2}$ correlation explains 37,1 and $43 \%$ of the data at DVE, TPA and OLF, respectively. The slopes of these relationships for the field based data are also lower than that predicted based on the emission estimates. The lesser agreement and lower slope for the $\mathrm{GOM} / \mathrm{SO}_{2}$ versus the $\mathrm{NO}_{\mathrm{x}} / \mathrm{SO}_{2}$ relationships may reflect: (1) an inaccurate emission estimate; (2) reduction of GOM to GEM in the power plant plume (cf. Lohman et al., 2006); (3) $\mathrm{SO}_{2}$ being measured being derived from another source; or 4) an artifact of measurement the GOM measurement. Data from earlier work at OLF also showed a lower proportion of GOM than expected 


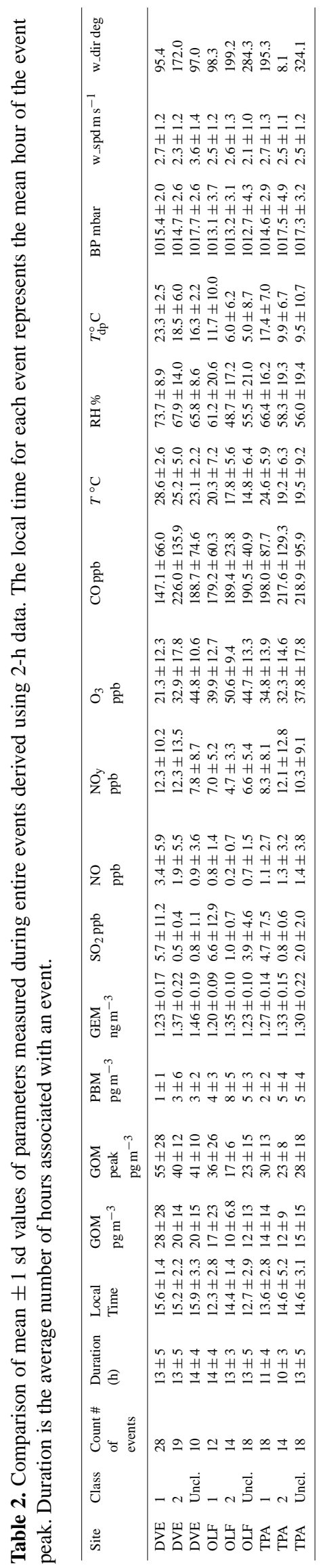


Table 3. Pearson correlation coefficients $(r)$ for 2 -week integrated GOM dry deposition to a surrogate surface $\left(\mathrm{GOM}_{\mathrm{SS}}\right)$ and GOM uptake to a passive sampler $\left(\mathrm{GOM}_{\mathrm{PS}}\right)$ with the number of GOM enhancement events occurring during the 2-w period and 2-w mean GOM concentrations at three sites as measured with the Tekran over the entire study. Bold type indicates a significant correlation with $p<0.05$.

\begin{tabular}{lrrrrc}
\hline & $\begin{array}{r}\text { No. of all } \\
\text { types events }\end{array}$ & $\begin{array}{r}\text { No. of Class 1 } \\
\text { events }\end{array}$ & $\begin{array}{r}\text { No. of Class 2 } \\
\text { events }\end{array}$ & $\begin{array}{r}\text { No. of Unclass. } \\
\text { events }\end{array}$ & $\begin{array}{r}\text { 2-w mean } \\
\text { GOM conc. }\end{array}$ \\
\hline DVE SS & $\mathbf{0 . 4 7}$ & $\mathbf{0 . 4 7}$ & 0.33 & -0.16 & 0.38 \\
OLF SS & $\mathbf{0 . 5 9}$ & -0.04 & $\mathbf{0 . 6 9}$ & $\mathbf{0 . 4 0}$ & $\mathbf{0 . 5 1}$ \\
TPA SS & $\mathbf{0 . 4 8}$ & 0.13 & -0.08 & $\mathbf{0 . 6 6}$ & $\mathbf{0 . 5 6}$ \\
DVE PS & $\mathbf{0 . 4 9}$ & 0.06 & -0.20 & 0.33 & $\mathbf{0 . 4 5}$ \\
OLF PS & 0.27 & $\mathbf{0 . 5 1}$ & $\mathbf{0 . 5 1}$ & $\mathbf{0 . 6 6}$ & $\mathbf{0 . 5 9}$ \\
TPA PS & -0.14 & 0.26 & -0.04 & -0.02 & $\mathbf{0 . 4 1}$ \\
\hline
\end{tabular}

based on emission inventories (Edgerton et al., 2006; WeissPenzias et al., 2011).

Class 2 events occurred primarily in the winter and spring at OLF (13 of 14) and TPA (6 of 8) and were evenly split at DVE between winter/spring ( 9 of 19) and summer/fall (10 of 19) (see Supplement Table 3). Class 2 events were characterized by lower mean dew point temperature $\left(T_{\mathrm{dp}}\right)$ and higher PBM and GEM concentrations at each site relative to Class 1 (Table 3). Mean $\mathrm{NO}$ was lower and $\mathrm{O}_{3}$ higher in Class 2, versus Class 1 events at DVE and OLF. These trends, as well as those described above, suggest synoptic air patterns were bringing air from outside the area to these two sites. One factor to consider for these events is that the mean GEM/CO ratios were similar for the Class $2(6.0,7.1$, and $6.1 \mathrm{pg} \mathrm{m}^{-3} \mathrm{ppb}^{-1}$ for DVE, OLF, and TPA; respectively) and Class 1 (8.0, 6.7, and $6 \mathrm{pg} \mathrm{m}^{-3} \mathrm{ppb}^{-1}$; respectively) events. The values suggest an input of industrial pollution based on the discussion in Slemr et al. (2009). Higher PBM measured during Class 2 events could be associated with industrial pollution with GOM being attached to aerosols at the colder conditions in the free troposphere. It has also been suggested that higher PBM concentrations are found near the tropopause (Murphy et al., 2006) and GOM is produced in the free troposphere/lower stratosphere (Lyman and Jaffe, 2012). As cool dry air descends from the free troposphere into the planetary boundary layer, the ratio of GEM: GOM: PBM could change.

Unclassified events occurred predominantly in the winter/spring at DVE (8 of 9) and TPA (12 of 16), but were split between seasons at OLF with most in the fall (6 of 17). Some Unclassified events at DVE did originate from the direction of EGPs, but at OLF and TPA they did not. At TPA and OLF, air associated with the Unclassified events had a low $T_{\mathrm{dp}}$. Mean $\mathrm{NO}$ and $\mathrm{NO}_{\mathrm{y}}$ for these events at DVE were less than that measured for other events, but at OLF and TPA these are comparable. Higher mean $\mathrm{O}_{3}$ concentrations also occurred during these events relative to Class 1 events. The mean $\mathrm{SO}_{2}$ for Unclassified events was greater than that for Class 2 events for each site, indicating that a component of $\mathrm{SO}_{2}$ in these events was not associated with nearby power plants. These characteristics suggest these events are similar to the Class 2 events but reflect mixing of local air with that descending.

Gridded Frequency Distribution diagrams were generated using trajectories for the five Class 1 and Class 2 events with the highest GOM concentrations at all three sites (Figs. 57). Class 1 events used are primarily isolated events (Supplement Table 3) except for 7 to 9 October. During these days, a Class 1 event occurred at DVE (16:30 LT) followed by an Unclassified event at TPA (17:30 LT), then a Class 1 event occurred at TPA (13:30 LT) and at DVE (14:30 LT), and finally, a Class 1 event occurred at TPA (11:30 LT) with a Class 2 event at DVE (15:30LT). Mean wind directions during these events suggest these are isolated events with the air not moving directly from one location to the other.

Horizontal locations at all altitudes generally show distinct patterns for the two classes of events (panels $a$ and $b$ in each figure). At DVE (Fig. 5), the differences in class type are the most discernible with transport predominantly from the east during Class 1 events, and more rapid transport from the northwest during Class 2 events. Removing grid cells that contain trajectory points below the modeled boundary layer height (panels c and d; Fig. 5) shows that chosen Class 2 events had a larger component of transport from the free troposphere compared to Class 1 events at DVE. This is in agreement with the drier conditions that are associated with Class 2 events (Table 3). Class 2 events at DVE also had distinct precipitation patterns (panel f), with most occurring in one transport arm to the WSW suggesting frontal movement across Florida during these events (panel e).

GFDs for OLF show that Class 2 events were associated with less precipitation at the upwind locations (Fig. 6f). During Class 1 events, the most predominant short-range $(<100 \mathrm{~km})$ transport was from the east indicating air coming into the site could have incorporated emissions from Plant Crist. However, long-range transport of emissions still may play a role in Class 1 events as can be seen in Fig. 6, where a subset of trajectories extends to the northwestern United States. This event had high $\mathrm{SO}_{2}$, relatively high $\mathrm{O}_{3}$ and low $T_{\mathrm{dp}}$ and occurred on 11/06/2009 (Supplement Table 2). This air mass could have entrained air from sources as it passed over the eastern United States. However 
the trajectories suggest the potential for longer range transport. The PBM during this event was also relatively high $\left(8 \mathrm{pg} \mathrm{m}^{-3}\right)$, as was $\mathrm{NO}_{\mathrm{y}}(12 \mathrm{ppb})$ and $\mathrm{CO}(185 \mathrm{ppb})$ suggesting an anthropogenic pollution component. The GFDs generated for the TPA events do not point towards a specific source for Class 1 events and the upper troposphere transport across the United States is shown for Class 2 events (Fig. 7).

\subsection{Analyses of event trends and data collected using the GOM passive sampler and surrogate surfaces}

Comparing the number of Tekran ${ }^{\circledR}$ derived events with the passive sampler uptake and surrogate surface deposition shows the best correlation for events recorded at OLF (Table 3). There is a good correlation between the $\mathrm{GOM}_{\mathrm{ss}}$ deposition and the Class 2 and Unclassified events measured at this location, however not for the Class 1 events. The only other correlations are for the $\mathrm{GOM}_{\mathrm{ss}}$ deposition with number of Class 1 events at DVE and with Unclassified events at TPA (Table 3). This indicates that either the passive systems are not recording events or that the Tekran system as configured, is best measuring the form(s) of $\mathrm{Hg}$ (II) that are prevalent at OLF and not that at DVE and TPA.

\section{Conclusions}

Each site was different in terms of potential $\mathrm{Hg}$ inputs but in general similar in local atmospheric chemistry with $\mathrm{O}_{3}$ high in the afternoon, $\mathrm{CO}, \mathrm{NO}_{\mathrm{y}}, \mathrm{NO}$ peaking in the morning, and all sites having a morning peak in $\mathrm{SO}_{2}$. Despite the similar trends, the magnitude of the peaks for $\mathrm{Hg}$ and other pollutants varies by site. OLF was the least impacted site with respect to point and nonpoint sources. If the dry deposition measured in the summer at OLF represents a "natural background" value for Florida $\left(0.03 \mathrm{ng} \mathrm{m}^{-2} \mathrm{~h}^{-1}\right)$, then deposition in the fall (as measured by the surrogate surfaces) was not significantly impacted by the nearby EGP because deposition remained the same. Deposition at this site was highest in the spring $\left(0.11 \mathrm{ng} \mathrm{m}^{-2} \mathrm{~h}^{-1}\right)$, and based on trajectory analyses in this paper and from previous work, this is due to inputs from outside of the local area and long range transport.

At TPA, deposition (mean annual $0.20 \mathrm{ng} \mathrm{m}^{-2} \mathrm{~h}^{-1}$ ) was above the assumed Florida background value, and mean seasonal values ranged from 0.16 to $0.24 \mathrm{ng} \mathrm{m}^{-2} \mathrm{~h}^{-1}$ for summer to spring. The additional spring input, if compared to the summer value, was $0.08 \mathrm{ng} \mathrm{m}^{-2} \mathrm{~h}^{-1}$ and similar to that at OLF. The higher values overall at TPA are attributed to local mobile source emissions facilitating GOM formation that was subsequently deposited.

At DVE seasonal deposition was lowest in the winter and summer (0.11 and $0.13 \mathrm{ng} \mathrm{m}^{-2} \mathrm{~h}^{-1}$, respectively) and above the background value for Florida. Deposition was highest in the fall and spring $\left(0.25\right.$ and $0.22 \mathrm{ng} \mathrm{m}^{-2} \mathrm{~h}^{-1}$, respectively. The peak afternoon GOM concentrations were highest in the fall when air was from the general direction of the wasteto energy facilities and thus, this facility is contributing either GOM or GEM that may be locally oxidized. This is supported by the fact that in winter traffic density is higher, deposition is lower, and the air was not derived from the direction of local EGPs. The lowest afternoon peak in GOM was also observed in the winter when the air was not coming from these facilities.

Based on $\mathrm{GOM}_{\mathrm{ss}}$ measured deposition, deposition velocities developed using the surrogate surface data, and Tekran ${ }^{\circledR}$ derived GOM concentrations, Peterson et al. (2012) suggested that the chemical forms of GOM varied between these sites spatially and temporally. Annual deposition to the surrogate surfaces at TPA and DVE were more than 2-fold greater than that measured OLF reflecting differences in chemistry, concentration and sources. This work showed that the collective use of information developed during periods of dry deposition in Florida could help understand potential sources of $\mathrm{Hg}$. However to allocate specific source contributions, the chemistry of the forms of $\mathrm{Hg}$ measured by the samplers and Tekran ${ }^{\circledR}$ system must be understood.

\section{Supplementary material related to this article is available online at: http://www.atmos-chem-phys.net/12/ 9201/2012/acp-12-9201-2012-supplement.pdf.}

Acknowledgements. This research was funded by EPRI. We thank the State of Florida and SEARCH personnel for deploying and shipping the samplers over the year of this study as well as maintaining the sampling sites; compiling the automated system data presented; and for performing the QA and operating these intensive monitoring sites. Special thanks to Melissa Markee and Cassandra Woodward for making the trek to Florida to establishing the field sites and coordinating the sampling and sample analyses. Much thanks to Musheng Alishahi who managed all aspects of this project and to Coty Weaver and Vanessa Wehrkamp for keeping the sampler flow going. Thanks also to Arnout ter Shure and Henry Fuelberg for review of this manuscript prior to submission.

Edited by: A. Dastoor

\section{References}

Amos, H. M., Jacob, D. J., Holmes, C. D., Fisher, J. A., Wang, Q., Yantosca, R. M., Corbitt, E. S., Galarneau, E., Rutter, A. P., Gustin, M. S., Steffen, A., Schauer, J. J., Graydon, J. A., Louis, V. L. St., Talbot, R. W., Edgerton, E. S., Zhang, Y., and Sunderland, E. M.: Gas-particle partitioning of atmospheric $\mathrm{Hg}(\mathrm{II})$ and its effect on global mercury deposition, Atmos. Chem. Phys., 12, 591-603, doi:10.5194/acp-12-591-2012, 2012.

Ariya, P. A., Peterson, K., Snider, G., and Amyot, M.: Mercury chemical transformations in the gas, aqueous and heterogeneous phases: state-of-the-art science and uncertainties, in: Mercury 
Fate and Transport in the Global Atmosphere, edited by: Mason, R. and Pirrone, N., Spring Science+Business Median, New York, NY, USA, 2009.

Biswas, S., Verma, V., Schauer, J., Cassee, F., Cho, A., and Sioutas, C.: Oxidative potential of semivolatile and non volatile particulate matter (PM) from heavy-duty vehicles retrofitted with emission control technologies, Environ. Sci. Technol., 43, 39053912, 2009.

Butler, T. J., Cohen, M. D., Vermeylen, F. M., Likens, G. E., Schmeltz, D., and Artz, R. S.: Regional precipitation mercury trends in the eastern USA, 1998-2005: Declines in the Northeat and Midwest, no trend in the Southeast, Atmos. Environ., 42, 1582-1592, 2008.

Calvert, J. G. and Lindberg, S. E.: Mechanisms of mercury removal by $\mathrm{O}-3$ and $\mathrm{OH}$ in the atmosphere, Atmos. Environ., 39, 33553367, 2005.

Castro, M. S., Moore, C., Sherwell, J., And Brooks, S. B.: Dry deposition of gaseous oxidized mercury in Western Maryland, Sci. Total Environ., 417, 232-240, 2012.

Draxler, R. R. and Hess, G. D.: Description of the HYSPLIT - 4 modeling system, NOAA Tech. Memo., ERL ARL-224, 24 pp., 1997.

Dvonch, J. T., Graney, J. R., Keeler, G. J., and Stevens, R. K.: Use of elemental tracers to source apportion mercury in South Florida precipitation, Environ. Sci. Technol., 24, 4522-4527, 1999.

Dvonch, J. G., Keeler, G. J., and Marsik, F. J.: The influence of meteorological conditions on the wet deposition of mercury in southern Florida, J. App. Meteorol., 44, 1421-1435, 2005.

Edgerton, E. S., Hartsell, B. E., and Jansen, J. J.: Mercury speciation in coal-fired power plant plumes observed at three surface sites in the southeastern U.S., Environ. Sci. Technol., 40, 4563-4570, 2006.

Engle, M. A., Tate, M. T., Krabbenhoft, D. P., Kolker, Allan, Olson, M. L., Edgerton, E. S., DeWild, J. F., and McPherson, A. K.: Characterization and cycling of atmospheric mercury along the central U.S. Gulf Coast, Appl. Geochem., 23, 419-437, 2008.

Engle, M. A., Tate, M. T., Krabbenhoft, D. P., Schauer, J. J., Kolker, A., Shanley, J. B., and Bothner, M. H.: Comparison of atmospheric mercury speciation and deposition at nine sites across central and eastern North America, J. Geophys. Res.-Atmos., 115, D18306, doi:10.1029/2010JD014064, 2010.

Feng, X., Lu, J. Y., Gregoire, C., Hao, Y., Banic, C. M., and Schroeder, W.: Analysis of inorganic mercury species associated with airborne particulate matter/aerosols: method development, Anal. Bioanal. Chem., 380, 683-689, 2004.

Finlayson-Pitts, B. J. and Pitts, J. N.: Chemistry of the Upper and Lower Atmosphere, Academic Press, San Diego, CA, USA, 969 pp., 2000.

Guentzel, J. L., Landing, W. M., Gill, G. A., and Pollman, C. D.: Processes influencing rainfall deposition of mercury in Florida, Environ. Sci. Technol., 35, 863-873, 2001.

Gustin, M. S. and Jaffe, D.: Reducing the uncertainty in measurement and understanding of mercury in the atmosphere, Environ. Sci. Technol., 44, 2222-2227, 2010.

Gustin, M. S.: Exchange of Mercury between the Atmosphere and Terrestrial Ecosystems, in: Environmental Chemistry and Toxicology of Mercury, edited by: Liu, G., Cai, Y., and O'Driscoll, N., John Wiley and Sons, 423-454, 2012.
Gustin, M. S., Lyman, S. N., Kilner, P., and Prestbo, E.: Development of a passive sampler for gaseous mercury, Atmos. Environ., 45, 5805-5812, 2011.

Holmes, C. D., Jacob, D. J., Corbitt, E. S., Mao, J., Yang, X., Talbot, R., and Slemr, F.: Global atmospheric model for mercury including oxidation by bromine atoms, Atmos. Chem. Phys., 10, 12037-12057, doi:10.5194/acp-10-12037-2010, 2010.

Hynes, A. J., Donohoue, D. L., Goodsite, M. E., and Hedgecock, I. M.: Our current understanding of major chemical and physical processes affecting mercury dynamics in the atmosphere and at the air-water/terrestrial interfaces, edited by: Mason, R., and Pirrone, N., in: Mercury Fate and Transport in the Global Atmosphere, Spring Science+Business Media, New York, NY, USA, 2009.

Landing, W. M., Caffrey, J. M., Nolek, S. D., Gosnell, K. J., and Parker, W. C.: Atmospheric wet deposition of mercury and other trace elements in Pensacola, Florida, Atmos. Chem. Phys., 10, 4867-4877, doi:10.5194/acp-10-4867-2010, 2010.

Lin, C.-J., Pongprueksa, P., Lindberg, S. E., Pehkonen, S. O., Byun, D., and Jang, C.: Scientific uncertainties in atmospheric mercury models 1: model science evaluation, Atmos. Environ., 40, 20672079, 2006.

Lindberg, S. E. and Stratton, W. J.: Atmospheric speciation concentrations and behavior of reactive gaseous mercury in ambient air, Environ. Sci. Technol., 32, 49-57, 1998.

Lohman, K., Seigneur, C., Edgerton, E. S., and Jansen, J. J.: Modeling mercury in power plant plumes, Environ. Sci. Technol., 40, 3848-3854, 2006.

Lyman, S. and Gustin, M. S.: Determinants of Atmospheric Mercury Concentrations in Reno, Nevada, U.S.A., Sci. Total. Environ., 408, 431-438, 2009.

Lyman, S. N. and Jaffe, D. A.: Formation and fate of oxidized mercury in the upper troposphere and lower stratosphere, Nature Geosci., 5, 114-117, 2012.

Lyman, S. N., Gustin, M. S., Prestbo, E. M., and Marsick, F. J.: Estimation of Dry Deposition of Atmospheric Mercury in Nevada by Direct and Indirect Methods, Environ. Sci. Technol., 41, 19701976, 2007.

Lyman, S. N., Gustin, M. S., Prestbo, E. M., Kilner, P. I., Edgerton, E., and Hartsell, B.: Testing and Application of Surrogate Surfaces for Understanding Potential Gaseous Oxidized Mercury Dry Deposition, Environ. Sci. Technol., 43, 6235-6241, 2009.

Lyman, S., Gustin, M. S., and Prestbo, E.: Development and use of passive samplers for determining reactive gaseous mercury concentrations, Atmos. Environ., 44, 246-252, 2010.

Marsik, F. J., Keeler, G. J., and Landis, M. S.: The dry-deposition of speciated mercury to the Florida Everglades: Measurements and modeling, Atmos. Environ., 41, 136-149, 2007.

Murphy, D. M., Hudson, P. K., Thomson, D. S., Sheridan, P. J., and Wilson, J. C.: Observations of mercury-containing aerosols, Environ. Sci. Technol., 40, 3163-3167, 2006.

National Atmospheric Deposition Program. Mercury Deposition Network (MDN): A NADP network. NADP Program Office, Illinois State Water Survey, Champaign, IL, http://nadp.sws.uiuc. edu/mdn/, (last access: 23 January 2012), 2012.

Pal, B. and Ariya, P. A.: Gas-phase HO center dot-initiated reactions of elemental mercury: Kinetics, product studies and atmospheric implications, Environ. Sci. Technol., 38, 5555-5566, 2004. 
Peterson, C., Gustin, M., and Lyman, S.: Atmospheric mercury concentrations and speciation measured from 2004 to 2007 in Reno, Nevada, USA, Atmos. Environ., 30, 4646-4654, 2009.

Peterson, C., Alishahi, M., and Gustin, M. S.: Testing the use of passive sampling systems for understanding air mercury concentrations and dry deposition across Florida, USA, Sci. Total Environ., 424, 297-309, 2012.

Prestbo, E. M. and Gay, D. A.: Wet deposition of mercury in the U.S. and Canada, 1996-2005: results and analysis of the NADP Mercury Deposition Network (MDN), Atmos. Environ., 43, 4223-4233, 2009.

Schroeder, W. H. and Munthe, J.: Atmospheric mercury - An overview, Atmos. Environ. 32, 809-822, 1998.

Seigneur, C., Wrobel., J., and Constantinou, E.: A chemical kinetic mechanism for atmospheric inorganic mercury, Environ. Sci. Technol., 28, 1589-1597, 1994.

Selin, N. E. and Jacob, D. J.: Seasonal and spatial patterns of mercury wet deposition in the United States: Constraints on the contribution from North American anthropogenic sources, Atmos. Environ., 42, 5193-5204, 2008.

Sillman, S., Marsik, F. J., Al-Wali, K. I., Keeler, G. J., and Landis, M. S.: Reactive mercury in the troposphere: Model formation and results for Florida, the northeastern United States, and the Atlantic Ocean, J. Geophys. Res., 112, D23305, doi:10.1029/2006JD008227, 2007.

Slemr, F., Ebinghaus, R., Brenninkmeijer, C.A. M., Hermann, M., Kock, H. H., Martinsson, B. G., Shuck, T., Sprung, D., van Velthoven, P., Zahn, A., and Ziereis, H.: Gaseous mercury distribution in the upper troposphere and lower stratosphere observed onboard the CARIBIC passenger aircraft, Atmos. Chem. Phys., 9, 1957-1969, doi:10.5194/acp-9-1957-2009, 2009.

Steffen, A., Scherz, T., Olson, M., Gay, D., and Blanchard, P.: Comparison of data quality control protocols for atmospheric speciation measurements, J. Environ. Monitor., 14, 752-765, 2012.
Stohl, A.: Computation, accuracy and applications of trajectories a review and bibliography, Atmos. Environ., 32, 947-966, 1998.

Stohl, A., Forster, C., Eckhardt, S., Spichtinger, N., Huntrieser, H., Heland, J., Schlager, H., Wilhelm, S., Arnold, F., and Cooper, O.: A backward modeling study of intercontinental pollution transport using aircraft measurements, J. Geophys. Res., 108, 4370, doi:10.1029/2002JD002862, 2003.

Subir, M., Ariya, P. A., and Dastoor, A. P.: A review of the uncertainties in atmospheric modeling of mercury chemistry I. Uncertainties in existing kinetic parameters : Fundamental limitations and the importance of heterogeneous chemistry, Atmos. Environ., 35, 5667-5676, 2011.

Subir, M., Ariya, P. A., and Dastoor, A. P.: A review of the sources of uncertainties in atmospheric mercury modeling II. Mercury surface and heterogeneous chemistry - A missing link, Atmos. Environ., 46, 1-10, 2012.

Weiss-Penzias, S., Gustin, M. S., and Lyman, S. N.: Observations of speciated atmospheric mercury at three sites in Nevada, USA: Evidence for a free tropospheric source of reactive gaseous mercury, J. Geophys. Res., 114, D14302, doi:10.1029/2008JD011607, 2009.

Weiss-Penzias, P. S., Gustin, M. S., and Lyman, S. N.: Sources of gaseous oxidized mercury and mercury dry deposition at two southeastern US sites, Atmos. Environ., 45, 4569-4579, 2011.

Wesley, M. L.: Parameterization of surface resistances to gaseous dry deposition in regional-scale numerical models, Atmos. Environ., 34, 2261-2282, 1989.

Zhang, L., Blanchard, P., Gay, D. A., Prestbo, E. M., Risch, M. R., Johnson, D., Narayan, J., Zsolway, R., Holsen, T. M., Miller, E. K., Castro, M. S., Graydon, V. L., Dalziel, J.: Estimation of speciated and total mercury dry deposition at monitoring locations in eastern and central North America. Atmos. Chem. Phys. 12, 4327-4340, doi:10.5194/acp-12-4327-2012, 2012. 